AL-MARSHAD: JURNAL ASTRONOMI ISLAM DAN ILMU-ILMU BERKAITAN

ISSN 2442-5729 (print) || ISSN 2598-2559 (online)

http://jurnal.umsu.ac.id/index.php/almarshad

DOI: 10.30596/jam.v\%vi\%i.3796 || Vol. 5, No. 2 Desember 2019

\title{
Akurasi Arah Kiblat Pemakaman Desa Ponteh Kecamatan Galis Kabupaten Pamekasan
}

\author{
Hosen $^{1^{*}}$, Eka Nurhalisa ${ }^{2}$ \\ Institut Agama Islam Negeri Madura*1,2 \\ ${ }^{*}$ email: hosen@iainmadura.ac.id \\ 2 email: ekanurhalisa@gmail.com
}

\begin{tabular}{|c|}
\hline Abstract \\
\hline $\begin{array}{l}\text { The Cemetery conditions in Ponteh Village, Galis Sub } \\
\text { district, Pamekasan Regency do not appear in line and seem } \\
\text { messy both from the shaf rows and the kiblah direction of } \\
\text { the cemetery. In this article there are two main issues that } \\
\text { are the focus of the problem. First, how is the method of } \\
\text { determining the burial Kiblah direction at the Cemetery of } \\
\text { Ponteh Village, Galis District, Pamekasan Regency. And } \\
\text { second, how is the accuracy of the burial Kiblah direction in } \\
\text { the Cemetery of Ponteh Village, Galis District, Pamekasan } \\
\text { Regency. The location of this study is in three cemeteries in } \\
\text { Ponteh Village, Galis District. The method used is } \\
\text { qualitative phenomenological approach in the form of } \\
\text { descriptive analysis. Research data obtained from } \\
\text { interviews, observations and documentation. Data analysis } \\
\text { was carried out through the stages of data reduction, data } \\
\text { presentation, and drawing conclusions. The results show; (1) } \\
\text { The method used by the community in determining the } \\
\text { cemetery kiblah direction is by estimating and beliefs based } \\
\text { solely on feelings called the taqribi method by facing } \\
\text { westward and then slightly tilted to the north. There is also } \\
\text { an excavation of the burial ground following the direction of } \\
\text { the cemetery location and the position of the burial ground } \\
\text { located next to it. Second, according to the calculation result } \\
\text { of Islamic astronomy, the direction of the cemetery Ajih } 66^{\circ} \\
9 \text { '53.7 "(N-W), the Cemetery of Bângger } 66^{\circ} 9 \text { ' } 50.87 " \text { (N- } \\
\text { W), and the Cemetery of Kaèl } 66^{\circ} 9 \text { ' } 48.93 \text { "(N -W). The } \\
\text { accuracy analysis result of the Kiblah direction of each } \\
\text { cemetery which samples are } 50 \text { tombs in groups obtained } \\
\text { was the cemetery that using data according to the calculation } \\
\text { of Kiblah, for Ajih Cemetery } 3 \text { graves ( } 6 \%) \text {, Bânger's } \\
\text { cemetery } 6 \text { graves ( } 12 \%) \text { and Kaèl zero graveyard ( } 0 \% \text { ). } \\
\text { Less to the north of } 1{ }^{\circ}-5{ }^{\circ} \text {, the Ajih cemetery } 14 \text { graves } \\
\text { ( } 28 \%) \text {, Bânger cemetery are } 26 \text { graves ( } 52 \%) \text { and Kaèl } \\
\text { cemetery are } 11 \text { graves ( } 22 \%) \text {. Less to the south } 1{ }^{\circ}-55^{\circ} \text { less } \\
\text { to the south, Ajih Cemetery } 2 \text { graves ( } 4 \%) \text {, the Bârger }\end{array}$ \\
\hline
\end{tabular}




\section{AL-MARSHAD: JURNAL ASTRONOMI ISLAM DAN ILMU-ILMU BERKAITAN \\ ISSN 2442-5729 (print) || ISSN 2598-2559 (online) \\ http://jurnal.umsu.ac.id/index.php/almarshad \\ DOI: 10.30596/jam.v\%vi\%i.3796 || Vol. 5, No. 2 Desember 2019}

Cemetery 3 graves (6\%) and the Kaèl cemetery is nil (0\%). Deviation of $6^{\circ}-10^{\circ}$ less to the north, Ajih cemetery is zero graveyard $(0 \%)$, Bânger Cemetery are 3 graves $(6 \%)$ and Kaèl cemetery is zero $(0 \%)$. Deviations from $6^{\circ}-10^{\circ}$ to the south, for Ajih Cemetery 30 graves $(60 \%)$, the Bânger cemetery are 11 graves $(22 \%)$ and the Kaèl cemetery are 14 graves $(28 \%)$. And those which stray northward $10^{\circ}$ and above are not found in all the camps. However, the deviation of the Kiblah direction of more than $10^{\circ}$ to the south was found in the Ajih cemetery and Bânger cemetery, each with 1 grave $(2 \%)$, and the Kaèl cemetery 25 graves $(50 \%)$

\section{Key Word : Accuration, Kiblah Direction, Cemetery, Burial Ground}

\section{Abstrak}

Kondisi pemakaman di Desa Ponteh Kecamatan Galis Kabupaten Pamekasan terlihat tidak berderet rapi dan terkesan berantakan baik dari barisan shaf maupun arah kiblat pemakaman. Dalam artikel ini ada dua hal pokok yang menjadi fokus problematika. Pertama, bagaimana metode penentuan arah kiblat penguburan jenazah di Pemakaman Desa Ponteh Kecamatan Galis Kabupaten Pamekasan. Dan kedua, bagaimana akurasi arah kiblat penguburan jenazah di Pemakaman Desa Ponteh Kecamatan Galis Kabupaten Pamekasan. Lokasi penelitian ini bertempat di tiga pemakaman yang terdapat di Desa Ponteh Kecamatan Galis. Metode yang digunakan adalah pendekatan kualitatif fenomenologis dalam bentuk analisis deskriptif. Data-data penelitian diperoleh dari hasil wawancara, observasi dan dokumentasi. Analisis data dilakukan melalui tahapan reduksi data, penyajian data, dan penarikan kesimpulan. Hasilnya menunjukkan; (1) metode yang dipakai oleh masyarakat dalam menentukan arah kiblat pemakaman adalah menggunakan perkiraan dan sebatas keyakinan semata berdasarkan perasaan disebut dengan metode taqribi $\bar{\imath}$ dengan cara menghadapkan ke arah barat lalu sedikit di miringkan ke utara. Terdapat juga penggalian kubur mengikuti arah lokasi pemakaman dan posisi makam yang terdapat disebelahnya. Kedua, menurut hasil perhitungan ilmu falak, arah kiblat pemakaman Ajih $66^{\circ} 9^{\prime}$ 53.7” (U-B), pemakaman Bânger 66 9' 50,87” (U-B), dan pemakaman Kaèl $66^{\circ}$ 9' 48,93" (U-B). Hasil analisis 


\section{AL-MARSHAD: JURNAL ASTRONOMI ISLAM DAN ILMU-ILMU BERKAITAN \\ ISSN 2442-5729 (print) || ISSN 2598-2559 (online) \\ http://jurnal.umsu.ac.id/index.php/almarshad \\ DOI: 10.30596/jam.v\%vi\%i.3796 || Vol. 5, No. 2 Desember 2019}

akurasi arah kiblat masing-masing pemakaman yang sampelnya 50 makam secara berkelompok diperoleh data kuburan yang arah kiblatnya sesuai perhitungan, untuk di pemakaman Ajih 3 kuburan (6\%), pemakaman Bânger 6 kuburan (12\%) dan pemakaman Kaèl nihil (0\%). Kurang ke utara $1^{\circ}-5^{\circ}$, pemakaman Ajih 14 makam (28\%), pemakaman Bânger 26 makam (52\%) dan pemakaman Kaèl 11 makam (22\%). Kurang ke selatan $1^{\circ}-5^{\circ}$ kurang ke selatan, pemakaman Ajih 2 makam (4\%), pemakaman Bânger 3 makam (6\%) dan pemakaman Kaèl nihil (0\%). Deviasi $6^{\circ}-10^{\circ}$ kurang ke utara, pemakaman Ajih nihil $(0 \%)$, pemakaman Bânger 3 kuburan $(6 \%)$ dan pemakaman Kaèl nihil $(0 \%)$. Penyimpangan $6^{\circ}-10^{\circ}$ ke selatan, untuk pemakaman Ajih 30 kuburan (60\%), pemakaman Bânger 11 kuburan (22\%) dan pemakaman Kaèl 14 kuburan (28\%). Dan yang melenceng ke utara $10^{\circ}$ keatas tidak ditemukan di semua pamekaman. Akan tetapi yang deviasi arah kiblatnya lebih dari $10^{\circ}$ ke selatan ditemukan di pemakaman Ajih dan pemakaman Bânger masing-masing 1 kuburan (2\%), dan pemakaman Kaèl 25 kuburan (50\%).

\section{Kata Kunci: Akurasi, Arah Kiblat, Pemakaman, Kuburan}

\section{A. Pendahuluan}

Islam merupakan agama yang komplit dari segi apapun. Lebih-lebih dalam masalah ibadah. Baik ibadah mahḍh (yang berhubungan dengan Allah/habl min Allāh) maupun gair mahdah (ibadah yang berhubungan dengan sesama manusia/habl min al$n \bar{a} s)$. Baik kewajiban yang berupa fard 'ain (bersifat individual) maupun fard kifāyah (bersifat kolektif). Diantara kewajiban yang bersifat kolektif adalah masalah perawatan jenazah. Hal-hal yang harus dilakukan kepada orang yang sudah wafat adalah menyelesaikan hak jenazahnya yang diawali sejak menyiapkan, memandikan, mengkafani, menyalatkan, hingga menguburkan. Menguburkan jenazah merupakan proses terakhir dari perawatan jenazah. Diwajibkan untuk menguburkan jenazah sekalipun jenazah tersebut adalah orang kafir. Ada beberapa hal dan aturan tentang bagaimana menguburkan jenazah yang disusun berdasarkan sunnah dan ajaran yang dicontohkan oleh Rasulullāh. Dari sekian banyak tuntunan tersebut, 


\section{AL-MARSHAD: JURNAL ASTRONOMI ISLAM DAN ILMU-ILMU BERKAITAN \\ ISSN 2442-5729 (print) || ISSN 2598-2559 (online) \\ http://jurnal.umsu.ac.id/index.php/almarshad \\ DOI: 10.30596/jam.v\%vi\%i.3796 || Vol. 5, No. 2 Desember 2019}

diantaranya adalah menguburkan jenazah dengan menghadap arah kiblat. ${ }^{1}$

Kiblat adalah bagian yang tak terpisahkan dengan umat Islam dalam menjalankan ibadahnya. Merupakan salah satu syarat sahnya shalat, wajib dilakukan ketika hendak mengerjakan shalat dan juga ketika menguburkan jenazah. Perkara yang disunnahkan ketika melakukan adzan, doa, dzikir, belajar, membaca al-Qur`ān, menyembelih binatang dan sebagainya serta haram ketika sedang membuang air besar dan kecil. ${ }^{2}$

Perkara menghadap ke arah kiblat bukanlah hal yang bisa dianggap sepele dan remeh. Dalam al-Qur`ān kata kiblat diulang-ulang sebanyak empat kali. $^{3}$ Dan kata Ka'bah diulang sebanyak enam kali. ${ }^{4}$ Dapat disimpulkan bahwa Allāh dan RasulNya menaruh perhatian khusus terhadap arah kiblat.

${ }^{1}$ M. Nashiruddin Albani, Fiqh Lengkap Mengurus Jenazah, trans. A.M. Basalamah (Jakarta: Gema Insani Press, 2014), h. 112.

${ }^{2}$ Ahmad Izzan and Iman Saifullah, Studi Ilmu Falak: Cara Mudah Belajar Ilmu Falak (Banten: Pustaka Aufa Media Press, 2013), h. 99.

3 Achmad Mulyadi, Ilmu Hisab Rukyat (Surabaya: Pena Salsabila, 2013), 13.

4 Ahsin W. Hafidz, Kamus Ilmu alQur`an (Jakarta: Amzah, 2012), h. 142.
Dalam firman-Nya dikatakan:

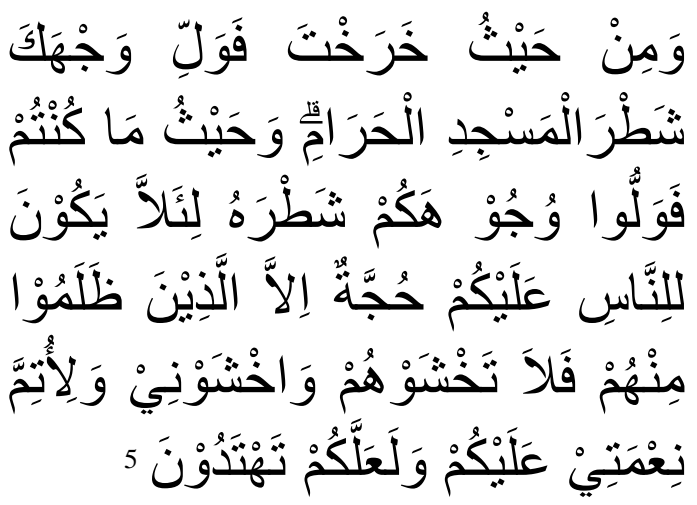

"Dan dari mana pun engkau (Muhammad) keluar, maka hadapkanlah wajahmu ke arah Masjid al-Haram. Dan di mana saja kamu berada, maka hadapkanlah wajahmu ke arah itu, agar tidak ada alasan bagi manusia (untuk menentangmu), kecuali orang-orang yang zalim di antara mereka. Janganlah kamu takut kepada mereka, tetapi takutlah kepada-Ku, agar Aku sempurnakan nikmat-Ku kepadamu, dan agar kamu mendapat petunjuk." 6

Kiblat Indonesia yang mayoritas penduduknya beragama Islam adalah menghadap ke barat laut dengan posisi bervariasi sesuai dengan letak geografis masing-masing. ${ }^{7}$ Disinilah peran ilmu

${ }^{5}$ al-Qurân, al-Baqarah (2) : 150.

6 Departemen Agama RI, Syaamil alQur'an The Miracle 15 in 1 (Bandung: PT. Sygma Examedia Arkanleema, 2009), h. 43.

7 KH. Ma'ruf Amin et al., Himpunan Fatwa Majelis Ulama Indonesia Sejak 1975, ed. Hijrah Saputra, Andriyansyah, and Adhika Prasetya K., 14th ed. (Jakarta: Erlangga, 2011), h. 261. 


\section{AL-MARSHAD: JURNAL ASTRONOMI ISLAM DAN ILMU-ILMU BERKAITAN \\ ISSN 2442-5729 (print) || ISSN 2598-2559 (online) \\ http://jurnal.umsu.ac.id/index.php/almarshad \\ DOI: 10.30596/jam.v\%vi\%i.3796 || Vol. 5, No. 2 Desember 2019}

falak dibutuhkan untuk menentukan arah kiblat shalat dan arah kiblat penguburan jenazah. Ilmu Falak mempunyai empat bahasan utama yang meliputi; penentuan arah kiblat, penentuan awal waktu shalat, penentuan awal bulan qamariyah untuk pelaksanaan puasa, haji, dan hari-hari besar lainnya serta untuk menentukan kapan terjadinya gerhana (bulan dan matahari). ${ }^{8}$

Akurasi atau kalibrasi arah kiblat yang dilakukan oleh para peneliti ratarata berkisar kepada masjid dan mushalla. Dalam penelitian ini penelitian mencoba untuk melakukan akurasi arah kiblat terhadap lokasi pemakaman. Hal ini dilakukan karena lokasi pemakaman hampir tidak ada yang menjadikan obyek penelitian dalam ranah kiblatnya. Penelitian ini berlokasi di pemakaman umum Desa Ponteh Kecamatan Galis Kabupaten Pamekasan. Terdapat tiga lokasi pemakaman yang dijadikan obyek penelitian, yaitu Pemakaman Ajih Dusun Kramat, Pemakaman Bânger Dusun Langtolang, dan Pemakaman Kaèl Dusun Karangpanasan.

${ }^{8}$ Mulyadi, Ilmu Hisab Rukyat, h. 3.
Observasi awal yang peneliti dapatkan dari Pemakaman Bânger sebagai salah satu pemakaman tertua di Desa Ponteh, terlihat masing-masing kuburan menghadap mengikuti kuburan yang berada di pinggir pemakaman yaitu menghadap utara-selatan sesuai dengan titik arah mata angin utama. Akan tetapi posisi kuburan yang terletak di tengah pemakaman tidak lurus mengikuti kuburan yang berada di pinggir pemakaman. Banyak kuburan yang berada di posisi tengah menghadap agak miring ke utara. Terlihat pula barisan-barisan kuburan tidak rapi dan terkesan berantakan. ${ }^{9}$ Dari pengamatan ini diketahui kebanyakan kuburan tidak berada dalam posisi yang sama.

Seklipun menentukan arah kiblat amat penting di kalangan umat Islam, namun kenyataannya dalam menentukan arah kiblat penguburan jenazah ini masyarakat Desa Ponteh khususnya hanya menggunakan perkiraan semata tanpa menggunakan cara atau metode yang jelas. Karena metodenya hanya bersifat perkiraan, maka arah kiblat yang dituju sebatas

9 Observasi lapangan, Pemakaman Bânger (30 Agustus 2018). 


\section{AL-MARSHAD: JURNAL ASTRONOMI ISLAM DAN ILMU-ILMU BERKAITAN \\ ISSN 2442-5729 (print) || ISSN 2598-2559 (online) \\ http://jurnal.umsu.ac.id/index.php/almarshad \\ DOI: 10.30596/jam.v\%vi\%i.3796 || Vol. 5, No. 2 Desember 2019}

perkiraan perasaan ketika berada di lokasi pemakaman. Itupun dengan menggunakan kaidah umum, bahwa arah kiblat adalah arah barat. Jadi, ketika jenazah sudah menghadap ke barat, maka dianggap cukup menghadap kiblatnya.

Hal ini menunjukkan bahwa tidak menuntut kemungkinan pemakaman lain yang berada di wilayah Desa Ponteh Kecamatan Galis Kabupaten Pamekasan arah kiblatnya kurang presisi. Bahkan diasumsikann lokasi pemakaman di wilayah lainnya arah kiblatnya banyak yang kurang tepat. Kesalahan dalam menentukan arah kiblat tidak bisa ditolerir jika mencapai $3^{\circ}$ lebih baik ke utara atau keselatan, karena akan mengakibatkan jauhnya arah kiblat dari wilayah Saudi Arabia. Kesalahan $\quad 5^{\circ}$ dari Pamekasan mengakibatkan penyimpangan arah kiblat \pm 750 km dari Kakbah. ${ }^{10}$

Tulisan ini akan membahas: bagaimana metode penentuan arah kiblat di Pemakaman Desa Ponteh Kecamatan Galis Kabupaten Pamekasan dan bagaimana akurasi arah kiblat di

\footnotetext{
10 Achmad Mulyadi, "Akurasi Arah Kiblat Masjid-Masjid di Kabupaten Pamekasan," Nuansa, 1, 10 (June 2013), h. 93.
}

Pemakaman Desa Ponteh Kecamatan Galis Kabupaten Pamekasan. Untuk menjawab persoalan tersebut, penulis melakukan serangkaian wawancara dengan para penggali kubur dan tokoh masyarakat setempat. Wawancara dilakukan untuk memperoleh informasi seputar penentuan arah kiblat ketika melakukan penggalian kubur di pemakaman Desa Ponteh Kecamatan Galis. Disamping itu, wawancara juga untuk mengetahui pemahaman para tokoh masyarakat tentang arah kiblat pemakaman khususnya orang Islam. Langkah selanjutnya untuk mengetahui akurasi arah kiblat pemakaman, penulis menggunakan peralatan kompas magnetik dan penggaris busur. Sebegai pelengkap untuk menentukan titik koordinat, penulis menggunakan aplikasi General Positioning System (GPS) yang diinstall pada Handphone.

\section{B. Metode Penelitian}

Penelitian ini menggunakan pendekatan kualitatif deskriptif. Sementara jenisnya bersifat field research yang lebih fokus kepada studi kasus. Data yang dikumpulkan dari responden/informan menggunakan wawancara semi terstruktur, observasi 


\section{AL-MARSHAD: JURNAL ASTRONOMI ISLAM DAN ILMU-ILMU BERKAITAN \\ ISSN 2442-5729 (print) || ISSN 2598-2559 (online) \\ http://jurnal.umsu.ac.id/index.php/almarshad \\ DOI: 10.30596/jam.v\%vi\%i.3796 || Vol. 5, No. 2 Desember 2019}

non partisipan dan dokumentasi. Untuk menggeneralkan obyek yang diteliti dengan menggukanan teknik cluster sampling terhadap pemakaman yang ada dimasing-masing lokasi. Analisis data dilakukan setelah seperangkat informasi dan fakta diperoleh melalui wawancara, observasi maupun dokumentasi. Data-data dimaksud kemudian dianalisis menggunakan pendekatan deduktif dengan cara reduksi (merangkum, memilih dan memfokuskan), penyajian naratif dan memverifikasi sereta menarik kesimpulan terhadap penentuan arah kiblat dan akurasinya di lokasi pemakaman.

\section{Landasan hukum menghadap kiblat}

Kiblat adalah Ka'bah yang dimuliakan oleh Allāh Swt. Dinamakan kiblat karena semua umat Islam harus menghadapkan tubuhnya ketika beribadah kepada Allāh, seperti ketika melaksanakan shalat. Dalam artian bahwa Ka'bah sebagai pusat umat Islam untuk melakukan ibadah sebagaimana yang Allāh Swt firmankan:

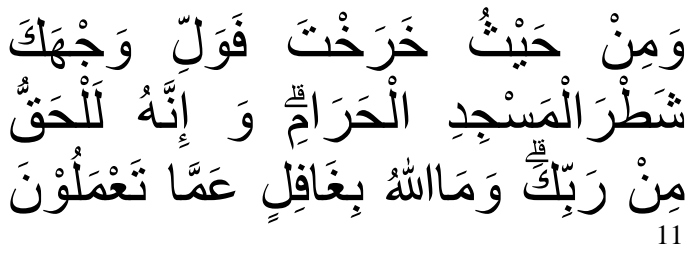

"Dan dari mana pun engkau (Muhammad) keluar, hadapkanlah wajahmu ke arah Masjidil Haram, sesungguhnya itu benar-benar ketentuan dari Tuhanmu. Allah tidak lengah terhadap apa yang kamu kerjakan. "12

Penyebutan Masjid al-Harām sebagaimana ayat diatas, dilalui dengan proses panjang dalam pengalihan kiblat dari Masjid al-Aqșā di Palestina ke Masjid al-Harām di Makkah yang di tengahnya terdapat Ka'bah. Allāh Swt mengabulkan permohonan pemindahan kiblat tersebut setelah 17 bulan Nabi Muhammad Saw menghadap Bait alMaqdis ketika melaksanakan shalat.

Selama itu pula nabi memohon kepada Allāh agar kiblat dapat dipindah ke Ka'bah di Makkah. Karena setiap mengucap salam selesai shalat menghadap Bait al-Maqdis, nabi selalu menengadahkan tangannya dan mengangkat kepalanya ke langit sambil

\footnotetext{
11 al-Qur`ān al-Baqarah (2) : 149.

12 Departemen Agama RI, Syaamil al-
} Qur'an The Miracle 15 in 1, h. 43. 


\section{AL-MARSHAD: JURNAL ASTRONOMI ISLAM DAN ILMU-ILMU BERKAITAN \\ ISSN 2442-5729 (print) || ISSN 2598-2559 (online) \\ http://jurnal.umsu.ac.id/index.php/almarshad \\ DOI: 10.30596/jam.v\%vi\%i.3796 || Vol. 5, No. 2 Desember 2019}

berdo'a agar kiblat dipindah ke Ka'bah yang lebih disukainya. ${ }^{13}$

Ayat pertama yang turun terkait pemindahan kiblat adalah ayat 144 dalam surat al-Baqarah;

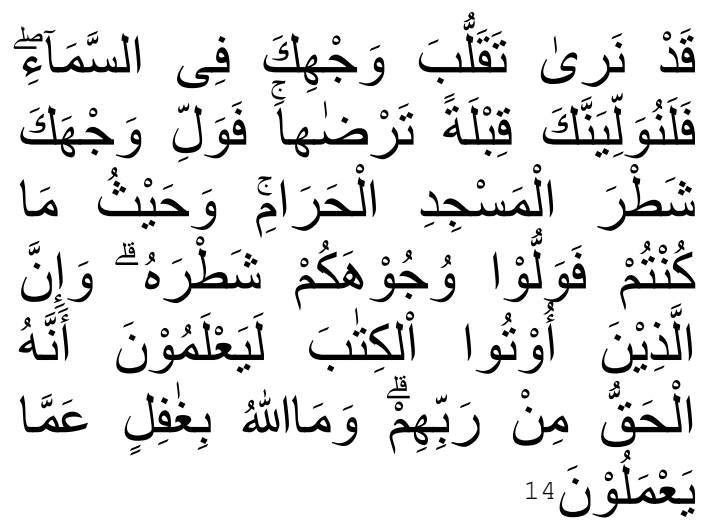

"Kami melihat wajahmu (Muhammad) sering menengadah ke langit, maka akan Kami palingkan engkau ke kiblat yang engkau senangi. Maka hadapkanlah wajahmu ke arah Masjidil haram. Dan di mana saja engkau berada, hadapkanlah wajahmu ke arah itu. Dan sesungguhnya orang-orang yang diberi Kitab (Taurat dan Injil) tahu, bahwa (pemindahan kiblat) itu adalah kebenaran dari Tuhan mereka. Dan Allah tidak lengah dari terhadap apa yang mereka kerjakan. "15

13 'Imād al-Dīn Abī al-Fidā' Ismā'îl bin Kas̀īr al-Damisyqī, Tafsīr al-Qur 'ān al-'Azīm, ed. Muștifā al-Sayyid Muhammad et al., I, vol. 2 (Kairo: Aulād al-Syaikh li al-Turās, 2000), h. 116. Lihat juga Khālid 'Abd al-Raḥmān al-'Ikk, Tashīl Al-Wușūl Ilā Ma'rifah Asbāb al-Nuzūl, I (Beirut: Dār al-Ma'rifah, 1998), h. 34-35.

14 al-Qur’ān al-Baqarah (2) : 144.

15 Departemen Agama RI, Syaamil alQur'an The Miracle 15 in 1, h. 41.
Ayat diatas turun ketika Nabi Muhammad Saw sudah hijrah ke Madinah. Sebagian pendapat mengatakan bahwa ayat tersebut diturunkan sekitar 6 atau 7 bulan. Perubahan kiblat dari Bait al-Maqdis ke Ka'bah di Makkah tidak lain merupakan permohonan nabi sendiri kepada Allāh Swt. Bahkan nabi meminta pertolongan Malaikat Jibrīl untuk mohon kepada Allāh Swt agar kiblat diubah sesuai permintaanya. Namun Malaikat Jibrīl menolaknya. Akhirnya nabi berdo'a disetiap selesai shalat agar kiblat diubah dari Masjid al-Aqșā ke Ka'bah. Karena nabi lebih senang berkiblat ke Ka'bah yang merupakan kiblat leluhurnya Nabi Ibrāhim as. ${ }^{16}$

Selain yang sudah termaktub dalam al-Qur’ān, landasan kewajiban menghadap kiblat adalah juga banyak tertulis dalam hadits. Diantaranya;

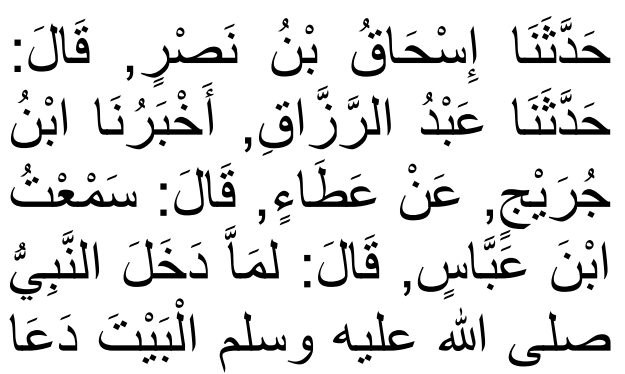

${ }^{16}$ Abī Muhammad al-Husain bin Mas'ūd al-Bagawī, Tasīr al-Bagawī Ma'̄̄lim al-Tanzīl, vol. 2 (Riyāḍ: Dār al-Ṭayyibah, 1409), h. 161. 


\section{AL-MARSHAD: JURNAL ASTRONOMI ISLAM DAN ILMU-ILMU BERKAITAN \\ ISSN 2442-5729 (print) || ISSN 2598-2559 (online) \\ http://jurnal.umsu.ac.id/index.php/almarshad \\ DOI: 10.30596/jam.v\%vi\%i.3796 || Vol. 5, No. 2 Desember 2019}

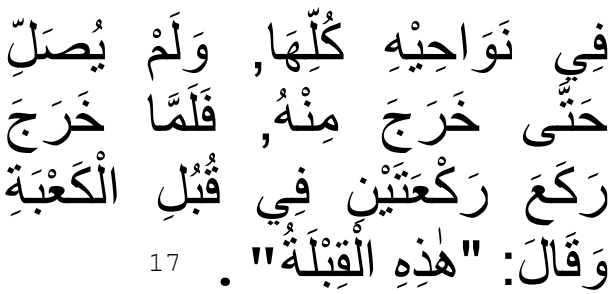

"Menceritakan kepada kami Ishāq bin Nașr, ia berkata: bercerita kepada kami 'Abdul Razzāq, mengabarkan kepada kami Ibn Juraij, dari 'Ațā' ia berkata: Saya mendengan Ibn 'Abbās pernah bilang; Setalah Nabi saw masuk ke Ka'bah, beliau berdo'a di setiap sisinya, dan beliau tidak melakukan shalat (di dalamnya) hingga keluar dari Ka'bah (al-Bait). Setelah beliau keluar (dari dalam Ka'bah), lalu shalat dua rakaát di depan Ka'bah, lalu bersabda: 'Inilah (Ka'bah) kiblat" "."

Hadis di atas secara kontekstual menjelaskan bahwa yang dimaksud kiblat itu adalah bangunan Ka'bah yang berbentuk hampir seperti kubus dan terlihat dari luar. Artinya bentuk utuh bangunan dari Ka'bah itu sendiri. Sementara di dalam Ka'bah tidak dianggap sebagai kiblat karena hanya terdiri dari dinding-dinding penyokongnya. Walhasil, yang dimaksud menghadap kiblat adalah menghadap ke fisik ( 'ain) Ka'bah bagi orang yang berada di Masjid al-Ḥarām.

${ }^{17}$ Abū 'Abdullāh Muhammad bin Ismā' 11 al-Bukhārī, al-Jāmi’ al-Ṣahīh, I, vol. 1 (Kairo: al-Salafiyyah, 1400), h.147.
Dan kepada arah posisi Ka'bah bagi orang yang jauh darinya.

\section{Konsep Arah kiblat}

Kiblat asalnya dari bahasa Arab al-qiblah yang memiliki makna 'hadapan'. Dan bisa juga diartikan sebagai Ka'bah. ${ }^{18}$ Pada dasarnya qiblah itu berarti jihah (arah). ${ }^{19}$ Kata qiblah merupakan salah satu bentuk masdar (derivasi) dari qabala-yaqbulu-qiblatan yang berarti 'menghadap' atau berarti arah. ${ }^{20}$ Dan yang dimaksud arah di sini adalah arah ke Ka'bah di Makkah. Makkah adalah kota suci bagi umat Islam seluruh dunia. $^{21}$

Arah kiblat secara terminologi ialah arah yang wajib dituju oleh umat Islam ketika melakukan ibadah shalat dan ibadah-ibadah lain. Dengan demikian yang dimaksud dengan kiblat secara terminologi adalah bangunan Ka'bah atau arah yang dituju kaum muslimin dalam melaksanakan sebagian

\footnotetext{
${ }^{18}$ Ahmad Warson Munawwir, Kamus AlMunawwir; Arab-Indonesia, 1st ed. (Yogyakarta: Pustaka Progresif, 1984), h. 1088.

19 Ibn Manzūr, Lisān al-'Arab, vol. 5 (Kairo: Dār al-Ma'ārif, n.d.), h. 3521.

${ }^{20}$ H. Harun Nasution et al., Ensiklopedi Islam Indonesia, vol. 2 (Jakarta: Djambatan, 1992), h. 637.

${ }^{21}$ Nasution et al., 2: 744.
} 


\section{AL-MARSHAD: JURNAL ASTRONOMI ISLAM DAN ILMU-ILMU BERKAITAN \\ ISSN 2442-5729 (print) || ISSN 2598-2559 (online) \\ http://jurnal.umsu.ac.id/index.php/almarshad \\ DOI: 10.30596/jam.v\%vi\%i.3796 || Vol. 5, No. 2 Desember 2019}

ibadah. $^{22}$ Pendapat lain mengatakan bahwa kiblat ialah suatu arah yang wajib dituju oleh umat Islam ketika melaksanakan ibadah shalat. ${ }^{23}$

Kiblat penting sekali bagi umat Islam, terutama di dalam mendirikan shalat. Ka'bah merupakan pusat kesatuan arah bagi umat Islam dalam mengerjakan shalat. Disamping itu umat Islam sering sekali mengutamakan arah kiblat dalam mengerjakan sesuatu selain shalat, misalnya ketika berwuḍu', berdoa, mengaji, memulai ihram dan dalam hal ini juga termasuk menguburkan jenazah.

Arah kiblat ditekankan pada arah terdekat dari suatu tempat dipermukaan bumi ke posisi Ka'bah di Makkah. Dan sesuai dengan teks ayat dalam surat alBaqarah (2) ayat 144, bahwa arah yang dimaksud adalah syathr. Aplikasi kata syathr yang memiliki arti 'separuh/setengah'24 atau 'sebagian'25

${ }^{22}$ H. Nasrun Haroen, Ensiklopedi Hukum Islam, ed. H. Abdul Aziz Dahlan et al., 1st ed., vol. 3 (Jakarta: Ichtiar Baru van Hoeve, 1996), h. 944 .

23 Moh. Murtadho, Ilmu Falak Praktis (Malang: UIN Malang Press, 2008), h. 126.

${ }^{24}$ Majd al-Dīn Muhammad bin Ya'qūb

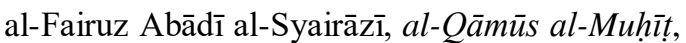
vol. 2 (Kairo: al-Hay`ah al-Mișriyyah, n.d.), h. 57. Lihat juga Ibn Manzūur, Lisān al-'Arab, vol. 4 (Kairo: Dār al-Ma'ārif, n.d.), h. 2261. ialah posisi hadap terdekat seseorang terhadap Ka'bah melalui garis lengkung bumi seperti gambar di bawah ini.

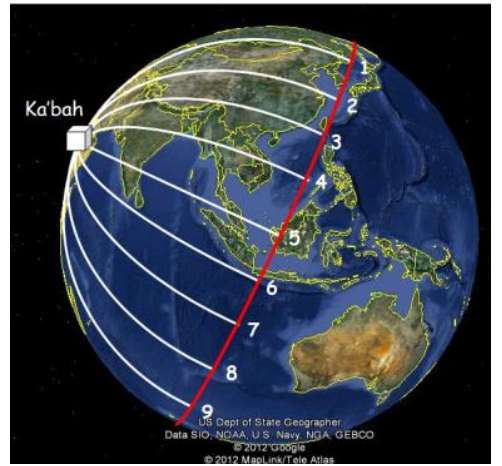

Posisi hadap ke Ka'bah di Makkah

\section{E. Ragam Metode penentuan arah kiblat}

Secara historis, penentuan arah kiblat di Indonesia sudah mengalami perkembangan yang signifikan sesuai dengan kualitas dan kapasitas intelektual kaum muslimin. Hal ini dapat diamati dari peralatan yang digunakan untuk mengukurnya, seperti miqyas, tongkat istiwa', rubu'mujayyab, kompas, Global Positioning System, theodolit dan software-software berbasis android yang dihubungkan dengan internet. Selain itu sistem perhitungan yang digunakanpun mulai berkembang, mulai dari data koordinat tempat ataupun sistem ilmu ukurnya. ${ }^{26}$

${ }^{25}$ al-Syairāzī, al-Qāmūs al-Muhīṭ, 2:57.

26 H. Susiknan Azhari, Ilmu Falak; Perjumpaan Khazanah Islam dan Sains Modern 


\section{AL-MARSHAD: JURNAL ASTRONOMI ISLAM DAN ILMU-ILMU BERKAITAN \\ ISSN 2442-5729 (print) || ISSN 2598-2559 (online) \\ http://jurnal.umsu.ac.id/index.php/almarshad \\ DOI: 10.30596/jam.v\%vi\%i.3796 || Vol. 5, No. 2 Desember 2019}

Ragam penentuan arah kiblat berkembang dari yang sangat tradisional sampai pada yang modern sesuai perkembangan ilmu dan teknologi.

Dalam menentukan arah kiblat paling tidak model yang digunakan ada dua, pertama; model taqribī (perkiraan). Metode ini cukup sederhana, yaitu mengetahui arah mata angin utama, yakni utara, timur, selatan da barat. Cara mengukurnyapun sederhana. Cukup mengetahui posisi Ka'bah di Makkah ditinjau dari lokasi pengukuran. Apakah arahnya lurus, miring ke kanan atau ke kiri sesuai arah mata angin tersebut. Karena sifatnya perkiraan, maka akurasinya tentunya sangat rendah. Model seperti ini biasanya menggunakan alat bantu seperti kompas, pisau silet dan atau tongkat istiw $\bar{a} \cdot{ }^{27}$

Kedua, model tahquīqì. Metode ini dikerjakan melalui perhitungan matematika dengan pendekatan rumusrumus ilmu ukur segitiga bola (trigonometri). Perhitungannya tidak lain untuk mencari nilai sudut arah

(Yogyakarta: Suara Muhammadiyah, 2007), h. 44.

${ }^{27}$ Mulyadi, Ilmu Hisab Rukyat, h. 26. kiblat. Yaitu nilai sudut yang dihasilkan dari sebuah segitiga bola yang sisisisinya berupa lingkaran-lingkaran besar yang saling berpotongan antara titik Ka'bah, lokasi pengukuran, dan titik utara bumi. Untuk di Indonesia nilai sudutnya bisa dengan modifikasi rumus. Misalnya nilai sudut arah kiblat yang dihasilkan dapat dibaca dengan menggunakan konsep azimut (utara, timur, selatan dan barat), dicara dari arah barat ke utara, atau dibaca dari arah utara ke barat. Tergantung modifikasi rumus yang digunakan. Nilai-nilai tersebut merupakan data terpenting dalam metode tahqūq $\bar{l}^{28}$

Karena Metode taḥqīq ini mengaplikasikan rumus spherical trigonometry yang didalammnya telah memperhitungkan bentuk bumi yang bulat, maka hasil yang diperoleh akurasinya sangat tinggi. Sangat berbeda dengan perhitungan arah yang menggunakan sistem koordinat Kartesius (dua dimensi) yang digunakan untuk bidang datar saja. Perhitungan arah kiblat harus memperhitungkan kelengkungan bumi, mengingat setiap titik di permukaan

28 Mulyadi, “Akurasi Arah Kiblat Masjid-Masjid di Kabupaten Pamekasan,” h. 83. 


\section{AL-MARSHAD: JURNAL ASTRONOMI ISLAM DAN ILMU-ILMU BERKAITAN \\ ISSN 2442-5729 (print) || ISSN 2598-2559 (online) \\ http://jurnal.umsu.ac.id/index.php/almarshad \\ DOI: 10.30596/jam.v\%vi\%i.3796 || Vol. 5, No. 2 Desember 2019}

bumi ini berada pada permukaan bola bumi. $^{29}$ Perhitungan arah kiblat membutuhkan alat hitung berupa daftar logaritma atau kalkulator. Saat ini alat hitung yang digunakan pada umumnya adalah calculator scientific, microsoft excel dan visual basic.

Data-data yang diperlukan dalam perhitungan ini antara lain; lintang dan bujur tempat yang akan dihitung dan juga Ka'bah. Rumus yang digunakan juga bervariasi sesuai dengan selera masing-masing pengukur. Misalnya;

Rumus $\quad \operatorname{Cotg} \mathrm{B}=\operatorname{cotg} \mathrm{b} \times \sin \mathrm{a}: \sin$ 1: $\quad c-\cos a x \operatorname{cotg} c$, dengan ketentuan sebagai berikut: $\mathrm{a}=90$ - lintang tempat $\mathrm{b}=90-$ lintang Ka'bah $\mathrm{c}=$ bujur tempat - bujur Ka'bah

Apabila diaplikasikan dalam perhitungan, langkah yang dilakukan adalah seperti dibawah ini:

$\begin{array}{lll}\text { Data } & \text { Lintang } & =-7^{\circ} 9^{\prime} \\ \text { koordinat: } & \text { Pamekasan } & \mathrm{LS}^{30} \\ & \text { Bujur } & =113^{\circ} 30^{\prime} \\ & \text { Pamekasan } & \mathrm{BT}^{31} \\ & \text { Lintang } & \end{array}$

${ }^{29}$ Muhammad Hadi Bashori, Pengantar Ilmu Falak: Pedoman Lengkap Tentang Teori dan Praktik Hisab, Arah Kiblat, Waktu Salat, Awal Bulan Qamariah \& Gerhana (Pustaka Al Kautsar, 2015), h. 117.

${ }^{30}$ Badan Hisab \& Rukyat Departemen Agama, Almanak Hisab Rukyat (Jakarta: Proyek Pembinaan Badan Peradilan Agama Islam, 1981), h. 266.

31 Badan Hisab \& Rukyat Departemen Agama, h. 266.

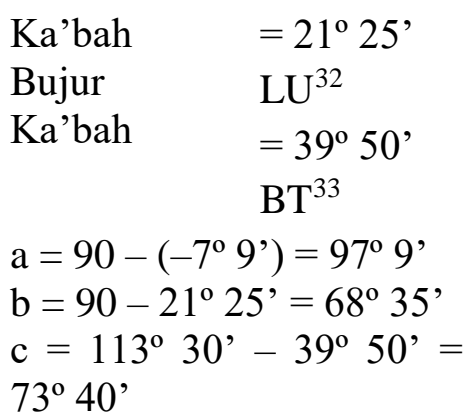

$\operatorname{Cotg} \mathrm{B}=\operatorname{cotg} \mathrm{b} x \sin \mathrm{a}: \sin \mathrm{c}-\cos \mathrm{a} \mathrm{x}$ $\operatorname{cotg} \mathrm{C}$

$\operatorname{Cotg} \mathrm{B}=\operatorname{cotg} 68^{\circ} 35^{\prime} \times \sin 97^{\circ} 9^{\prime}: \sin$ $73^{\circ} 40^{\prime}-\cos 97^{\circ} 9^{\prime} \times \operatorname{cotg} 73^{\circ} 40^{\prime}$

$\mathrm{B}=66^{\circ} 9^{\prime} 12.35^{\prime \prime}(\mathrm{U}-\mathrm{B})$, atau

$\mathrm{B}=23^{\circ} 50^{\prime} 47.65^{\prime \prime}(\mathrm{B}-\mathrm{U})$

Harga sudut arah kiblat Pamekasan adalah $66^{\circ} 9$ ' $12.35^{\prime}$ " dihitung sepanjang lingkaran horizon dari titik Utara ke Barat, atau 23 $3^{\circ} 50^{\prime} 47.65^{\prime \prime}$ dari titik Barat ke Utara.

$\begin{array}{ll}\text { Rumus } & \mathrm{C}=320^{\circ} 10^{\prime}+\mathrm{Lt} \text { (jika nilai } \\ \text { 2: } & \mathrm{C}>360, \text { maka dikurangi } \\ & \text { dahulu dengan } 360) \\ & \text { Sin } \mathrm{h}=(\sin \mathrm{pt} \mathrm{x} \text { sin } \mathrm{pk}+ \\ & \cos \mathrm{pt} \mathrm{x} \cos \mathrm{pk} \cos \mathrm{C}) \\ & \mathrm{Cos} \mathrm{Q}=(-\tan \mathrm{pt} \mathrm{x} \text { tan } \mathrm{h}+ \\ & \text { sin } \mathrm{pk}: \cos \mathrm{pt}: \cos \mathrm{h}) \\ & \text { Jika } \mathrm{C}>180, \text { maka azimut } \\ & \text { kiblat }=\mathrm{Q} \\ & \text { Jika } \mathrm{C}<180, \text { maka azimut } \\ & \text { kiblat }=360-\mathrm{Q} \\ \mathrm{pt}=\text { lintang tempat } \\ \mathrm{pk}=\text { lintang Ka'bah } \\ \mathrm{Lt}=\text { bujur tempat }\end{array}$

32 Badan Hisab \& Rukyat Departemen Agama, h. 69.

33 Badan Hisab \& Rukyat Departemen Agama, h. 69. 


\section{AL-MARSHAD: JURNAL ASTRONOMI ISLAM DAN ILMU-ILMU BERKAITAN \\ ISSN 2442-5729 (print) || ISSN 2598-2559 (online) \\ http://jurnal.umsu.ac.id/index.php/almarshad \\ DOI: 10.30596/jam.v\%vi\%i.3796 || Vol. 5, No. 2 Desember 2019}

Langkah perhitungannya seperti berikut:

$$
\begin{aligned}
& \mathrm{C}=320^{\circ} 10^{\prime}+\mathrm{Lt} \\
& \mathrm{C}=320^{\circ} 10^{\prime}+113^{\circ} 30^{\prime}=433^{\circ} 40^{\prime} \\
& \text { (karena lebih dari 360, } \\
& \text { dikurangan dahulu dengan } 360 \text { ) } \\
& \text { C }=433^{\circ} 40^{\prime}-360=\mathbf{7 3}^{\circ} \mathbf{4 0} \text { ' } \\
& \operatorname{Sin}=\left(\sin -7^{\circ} 9^{\prime} \times \sin 21^{\circ} 25^{\prime}+\cos -\right. \\
& \text { h } \left.\quad 7^{\circ} 9^{\prime} \times \cos 21^{\circ} 25^{\prime} \times \cos 73^{\circ} 40^{\prime}\right) \\
& \text { h }=12^{\circ} 22^{\prime} 32,61^{\prime \prime} \\
& \operatorname{Cos}=(-\tan \mathrm{pt} x \tan \mathrm{h}+\sin \mathrm{pk}: \cos \\
& \text { Q pt: } \cos h) \\
& \operatorname{Cos}=\left(-\tan -7^{\circ} 9^{\prime} \times \tan _{12^{\circ}} 22^{\prime}\right. \\
& \text { Q } 32,61^{\prime \prime}+\sin 21^{\circ} 25^{\prime}: \cos -7^{\circ} 9^{\prime} \text { : } \\
& \left.\cos 12^{\circ} 22^{\prime} 32,61^{\prime \prime}\right) \\
& Q=66^{\circ} 9^{\prime} 12,35 \text { ” }
\end{aligned}
$$

Karena nilai C $\left(73^{\circ} 40^{\prime}\right)<180$, maka azimut kiblatnya $=360-66^{\circ} 9^{\prime}, 12,35^{\prime \prime}$ $=293^{\circ} 50^{\prime} 47,6^{\prime \prime}$ UTSB (dihitung dari Utara, Timur, Selatan dan Barat).

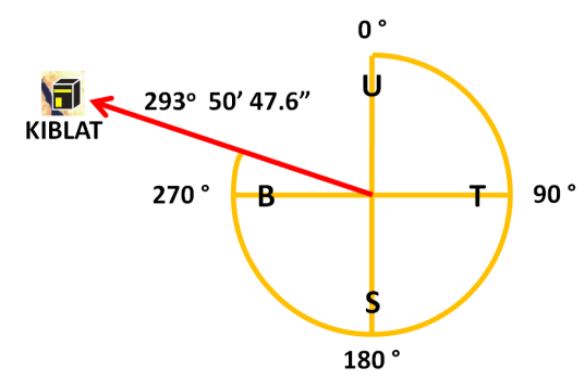

\section{Gambar azimut kiblat Pamekasan}

Dua rumus diatas aplikasinya harus dibantu dengan alat ukur khusus arah kiblat seperti; kompas magnetik, Mizwala Qibla Finder, Istiwā'ain, theodolit dan lainnya. Untuk akurasinya biasanya menggunakan bantuan sinar matahari. Karena dengan sinar matahari posisi kiblat dapat di tunjukkan dengan akurat sesuai dengan titik koordinatnya.
Hal ini berbeda dengan kompas magnetik. Arah utara yang ditunjukkan oleh kompas berdasarkan medan magnet yang belum dikoreksi dengan inklinasi/deklinasi magnet bumi.

Selain rumus diatas, dapat juga menggunakan bayangan matahari yang mengarah ke kiblat pada jam tertentu di hari tertentu pula sesuai dengan deklinasi dan perata waktu matahari. Metode ini adalah menghitung kapan bayangan sinar matahari membentuk bayangan yang mengarah ke kiblat di Makkah. Situasi seperti ini bisa terjadi pada pagi atau sore hari. Rumus yang digunakan adalah sebagai berikut:

$$
\begin{aligned}
\text { Tan } \mathrm{K} & =\operatorname{cotg} \mathrm{b} \times \sin \mathrm{a}: \sin \mathrm{c}-\cos \mathrm{a} \mathrm{x} \\
& \operatorname{cotg} \mathrm{c} \\
\mathrm{Az} & =90-\mathrm{K} \\
\text { Tan } \mathrm{P} & =\sin \mathrm{pt} \mathrm{x} \tan \mathrm{Az} \\
\text { Sin } \mathrm{Q} & =\tan \mathrm{dm}^{34} \mathrm{x} \sin \mathrm{P}: \tan \mathrm{pt} \\
\mathrm{BK} & =((\mathrm{Q}-\mathrm{P}): 15)+\mathrm{MP}-\mathrm{KWD} \\
\mathrm{MP} & =12-\mathrm{e}^{35} \\
\mathrm{KWD} & =(\mathrm{Lt}-\mathrm{w}): 15
\end{aligned}
$$

Contoh perhitungan memprediksi bayangan matahari mengarah ke kiblat di Kabupaten Pamekasan pada tanggal 2 Mei. Langkah perhitungannya sebagaimana dibawah ini:

\footnotetext{
${ }^{34}$ Muhyiddin Khazin, Kamus Ilmu Falak (Yogyakarta: Buana Pustaka, 2005), h. 51.

${ }^{35}$ H. Susiknan Azhari, Ensiklopedi Hisab Rukyat, 3rd ed. (Yogyakarta: Pustaka Pelajar, 2012), h. 68.
} 


\section{AL-MARSHAD: JURNAL ASTRONOMI ISLAM DAN ILMU-ILMU BERKAITAN \\ ISSN 2442-5729 (print) || ISSN 2598-2559 (online) \\ http://jurnal.umsu.ac.id/index.php/almarshad \\ DOI: 10.30596/jam.v\%vi\%i.3796 || Vol. 5, No. 2 Desember 2019}

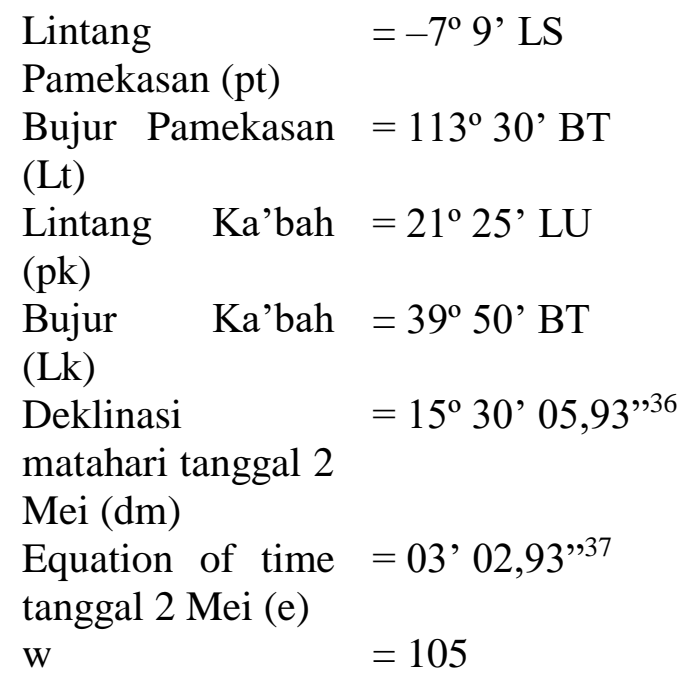

Data diatas kemudian disesuaikan dengan rumus yang sudah tersedia sebagaimana berikut:

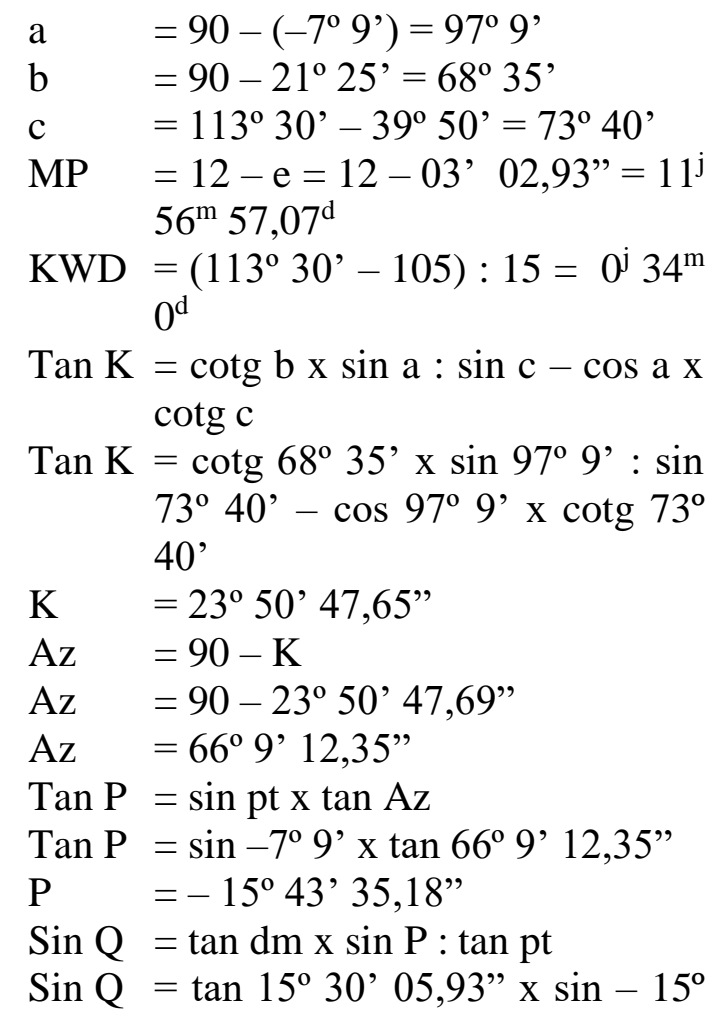

${ }^{36}$ Aḥmad Gazālī Muḥammad Fatḥullāh, Anfa' al-Wasīlah ilā Ma'rifah al-Auqāt alSyar'iyyah wa Simt al-Qiblah (Sampang: Ponpes al-Mubarak Lanbulan, n.d.), h. 42.

${ }^{37}$ Fathullāh, 42.

$$
\begin{array}{ll} 
& 43^{\prime} 35,18^{\prime \prime}: \tan -7^{\circ} 9^{\prime} \\
\text { Q } & =36^{\circ} 49^{\prime} 6,7^{\prime} \\
\text { BK } & =((Q-P): 15)+\mathrm{MP}-\mathrm{KWD} \\
\text { BK } & =\left(\left(36^{\mathrm{o}} 49^{\prime} 6,7^{\prime \prime}-\left(-15^{\mathrm{o}} 43^{\prime}\right.\right.\right. \\
& \left.\left.\left.35,18^{\prime}\right)\right): 15\right)+11^{\mathrm{j}} 56^{\mathrm{m}} 57,07^{\mathrm{d}}- \\
& 0^{\mathrm{j}} 34^{\mathrm{m}} 0^{\mathrm{d}} \\
\text { BK } & ={ }^{\mathrm{j}} 1453^{\mathrm{m}} 7,86^{\mathrm{d}} \text { WIB }
\end{array}
$$

Kesimpulannya bahwa bayangan sinar matahari mengarah ke kiblat pada tanggal 2 Mei terjadi pada jam 14:53:7,86 WIB. Selanjutnya adalah mengamati pada tanggal dan jam tersebut untuk memperoleh arah kiblat Pamekasan.

\section{F. Kajian Akurasi Arah Kiblat Pemakaman}

Sepanjang penelusuran penulis, terdapat beberapa kajian tentang akurasi arah kiblat pemakaman. Pertama, penelitian mengenai Uji Akurasi Arah Kiblat Pemakaman Berdasarkan Metode Sinus Cosinus (Studi di Kelurahan Purwodadi Kota Malang). Dalam penelitian ini peneliti menguji keakuratan arah kiblat pemakaman dengan menggunakan metode sinus cosinus. Dalam penelitian tersebut terdapat deviasi atau penyimpangan arah kiblat, rentan deviasi arah kiblat berkisar mulai dari $1^{\circ}, 15^{\circ}, 20^{\circ}, 25^{\circ}$ 


\section{AL-MARSHAD: JURNAL ASTRONOMI ISLAM DAN ILMU-ILMU BERKAITAN \\ ISSN 2442-5729 (print) || ISSN 2598-2559 (online) \\ http://jurnal.umsu.ac.id/index.php/almarshad \\ DOI: 10.30596/jam.v\%vi\%i.3796 || Vol. 5, No. 2 Desember 2019}

kurang ke utara dan $1^{\circ}$ kurang ke selatan..$^{38}$

Kedua, penelitian tentang Arah Kiblat Komplek Pemakaman Sewulan Kabupaten Madiun Berdasarkan Metode Imam Nawawi al-Bantani. Dalam penelitian ini peneliti menguji keakuratan arah kiblat di pemakaman Komplek Sewulan dengan menggunakan metode Imam Nawawi yang bersifat taqribi (pendekatan) dengan mengukur arah timur dan barat. Kemudian menandai lintang Makkah dan lintang Jawa. Hasil dalam penelitian ini adalah dari sejumlah pemakaman yang tidak tepat mengarah ke kiblat ditemukan rentan deviasi $2^{\circ}$, $4^{\circ}, 5^{\circ}, 8^{\circ}, 10^{\circ}, 15^{\circ}$, dan $4^{\circ}, 6^{\circ}$ yang melebihi dari arah kiblat yang sebenarnya. ${ }^{39}$

Ketiga, skripsi mengenai Penentuan Arah Qiblah Pemakaman (Persepsi Masyarakat dalam Penentuan Arah Qiblah Pemakaman di Kecamatan Ngunut Kabupaten Tulungagung). Dalam penelitian ini dipaparkan bahwa

38 Moch. Afifuddin, "Uji Akurasi Arah Kiblat Pemakaman Berdasarkan Metode Sinus Cosinus" (Skripsi, UIN Maliki, 2012).

${ }^{39}$ Kathon Bagus Kuncoro, "Arah Kiblat Komplek Pemakaman Sewulan Kabupaten Madiun Berdasarkan Metode Imam Nawawi alBantani” (Skripsi, UIN Maliki, 2016). berdasarkan rumus spherical trigonometri, pemakaman di lokasi penelitian banyak yang tidak sesuai arah kiblatnya. Karena metode penentuann arah kiblatnya menggunakan pedoman makam sebelumnya yang penentuan arah kiblatnya hanya kira-kira saja (taqribi). Sementara persepsi masyarakat mengenai arah kiblat pemakaman, secara umum mereka sama-sama menganggap bahwa mengarahkan mayat ke kiblat dalam proses penguburannya adalah perintah syari'ah. ${ }^{40}$

Keempat, Studi Analisis Metode Penentuan Arah Kiblat Maqbarah BHRD Kabupaten Rembang. Penelitian ini menganalisis pengecekan arah kiblat pemakaman di Kabupaten Rembang yang dilakukan secara massal dengan peralatan sederhana yang sudah disiapkan. Perhitungannya menggunakan data ephemeris hisab rukyat yang berlaku nasional. Namun dalam pelaksanaannya alat yang digunakan adalah kompas yang rentan dengan bahan-bahan berbau besi yang

${ }^{40}$ Misbahul Khoironi, "Penentuan Arah Qiblah Pemakaman (Persepsi Masyarakat dalam Penentuan Arah Qiblah Pemakaman di Kecamatan Ngunut Kabupaten Tulungagung)" (Skripsi, IAIN Tulungagung, 2018). 


\section{AL-MARSHAD: JURNAL ASTRONOMI ISLAM DAN ILMU-ILMU BERKAITAN \\ ISSN 2442-5729 (print) || ISSN 2598-2559 (online) \\ http://jurnal.umsu.ac.id/index.php/almarshad \\ DOI: 10.30596/jam.v\%vi\%i.3796 || Vol. 5, No. 2 Desember 2019}

dapat mengganggu kinerja keakuratan utara kompas. Sehingga hasilnya kurang maksimal karena akan terjadi selisih dengan hasil hitung peralatan modern seperti teodolite. ${ }^{41}$

Kelima, penelitian tentang Akurasi Arah Kiblat Komplek Pemakaman Ditinjau Menurut Kaidah Trigonometri (Studi Kasus di Kecamatan Syiah Kuala Kota Banda Aceh). Penelitian ini menggunakan metode Trigonometri yang diaplikasikan dengan kompas standar ukur kiblat yang disarankan oleh Kementerian Agama setempat. Obyek penelitian dilakukan terhadap sepuluh komplek pemakaman yang ada di Kecamatan Syiah Kuala. Hasil penelitian ini menunjukkan bahwa sebanyak $7,46 \%$ pemakaman di kecamatan tersebut yang sesuai dengan kaidah Trigonometri. Sementara pemakaman lainnya 92,54\% tidak sesuai dengan kaidah Trigonometri atau tidak sesuai arah kiblatnya. ${ }^{42}$

${ }^{41}$ Muhammad Mannan Ma'nawi, “Studi Analisis Metode Penentuan Arah Kiblat Maqbarah BHRD Kabupaten Rembang" (Skripsi, IAIN Walisongo, 2011).

42 Mohd. Kalam Daud and Muhammad Kamalussafir, "Akurasi Arah Kiblat Komplek Pemakaman Ditinjau Menurut Kaidah Trigonometri (Studi Kasus di Kecamatan Syiah
Obyek penelitian yang dilakukan pada empat penelitian diatas sama dengan obyek yang diteliti dalam tulisan ini, yaitu pemakaman umum. Hanya lokasinya yang berbeda-beda sesuai dengan pilihan masing-masing peneliti. Sedangkan metode yang dipakai dalam melakukan pengecekan terhadap kiblat pemakaman tersebut ada yang berbeda dan ada yang sama dengan metode yang digunakan dalam penelitian ini. Sekalipun metodenya sama, seperti spherical trigonometri misalnya, tapi rumus aplikasinya yang berbeda dengan rumus yang digunakan peneliti dalam tulisan ini.

\section{G. Jenazah dan Perawatannya}

Jenazah berasal dari kata bahasa Arab janaza yang berarti menutup. ${ }^{43}$ Kata jamaknya disebut janāiz. ${ }^{44}$ Kemudian menjadi kata serapan dalam bahasa Indonesia. Penekanan maknanya lebih kepada mayat atau mayyit sebagai makna dari kata al-jināzah atau aljanāzah. ${ }^{45}$ Ahli bahasa Arab berbeda pendapat tentang pemaknaan dari kata

Kuala Kota Banda Aceh)," Samarah, 2, 2 (July 2018): 502-29.

43 Ibn Manzūū, Lisān al-'Arab, vol. 1 (Kairo: Dār al-Ma'ārif, n.d.), h. 699.

44 Nasution et al., Ensiklopedi Islam Indonesia, 2:487.

${ }^{45}$ Manzūur, Lisān al-' Arab, n.d., 1:699. 


\section{AL-MARSHAD: JURNAL ASTRONOMI ISLAM DAN ILMU-ILMU BERKAITAN \\ ISSN 2442-5729 (print) || ISSN 2598-2559 (online) \\ http://jurnal.umsu.ac.id/index.php/almarshad \\ DOI: 10.30596/jam.v\%vi\%i.3796 || Vol. 5, No. 2 Desember 2019}

al-jināzah atau al-janāzah. Ada yang mengartikan sebagai mayat (al-mayyit) atau ranjang/keranda (al-sarīr). Atau diartikan kedua-duanya, keranda bersama mayatnya (al-sarīr ma' almayyit) atau mayat dengan kerandanya (al-mayyit bisarīih). ${ }^{46}$ Terlepas dari perbedaan pengertian bahasa tersebut, dalam tulisan ini lebih ditekankan kepada mayat atau mayyit, orang yang sudah meninggal dan dibungkus dengan kain kafan.

Adapun hal-hal yang harus dilakukan terhadap orang yang sudah meninggal adalah merawat jenazahnya dimulai dari memandikan, mengafani, menyalatkan, hingga menguburkannya. Menyelesaikan perawatan jenazah termasuk salah satu kewajiban umat Islam yang bersifat kifayah. Artinya kewajiban yang telah ditunaikan oleh sebagian orang, maka gugurlah kewajiban sebagian orang yang lain.

Memandikan jenazah hendaknya dilakukan dengan hitungan ganjil. Minimal tiga kali proses memandikan disesuaikan dengan kebutuhan masingmasing jenazah. Air yang digunakan

46 Muhammad Murtaḍā al-Husain̄̄ alZabīdī, Tāj al-'Arūs min Jawāhir al-Qāmūs, vol. 15 (Kuwait: al-Turāṡ al-'Arabī, 1960), h. 73. untuk memandikan jenazah sebaiknya dicampur dengan sidrin (daun bidara) atau yang serupa seperti, kapur barus, daun pandan atau sesuatu yang harum. Kecuali air yang akan digunakan untuk wuḍu' si mayyit. Memandikan jenazah disunnahkan dari anggota tubuh sebelah kanan dan anggota badan yang biasa dibasuh ketika wuḍu'. Ketika proses memandikan jenazah sebaiknya menggunakan kain pembersih atau yang sejenisnya. Kemudian digosokgosokkan di bawah kain penutup setelah pakaiannya dilepaskan. ${ }^{47}$

Langkah berikutnya setelah jenazah selesai dimandikan, adalah membungkusnya dengan kain kafan. Kain kafan harus mencukupi untuk menutup seluruh anggota tubuhnya. Kain kafan disunnahkan berawarna putih. Banyaknya lapisan kain kafan disesuaikan dengan jenis kelamin jenazah. Laki-laki lebih afḍal menggunakan tiga helai dan wanita lima helai kain kafan. Lima helai tersebut terdiri dari sarung, baju kurung, kerudung, dan pembungkus dua helai. Sebelum dibungkus, mayat diluluri dengan semacam cendana, yaitu wangi-

47 Albani, Fiqh Lengkap Mengurus Jenazah, h. 43-44. 


\section{AL-MARSHAD: JURNAL ASTRONOMI ISLAM DAN ILMU-ILMU BERKAITAN \\ ISSN 2442-5729 (print) || ISSN 2598-2559 (online) \\ http://jurnal.umsu.ac.id/index.php/almarshad \\ DOI: 10.30596/jam.v\%vi\%i.3796 || Vol. 5, No. 2 Desember 2019}

wangian yang biasa diperuntukkan bagi mayat, kecuali mayat yang sedang berihram. ${ }^{48}$ Hal ini dilakukan utuk mencegah mayat agar tidak cepat membusuk di dalam kuburnya.

Kegiatan berikutnya adalah menyalati jenazah. Disunnah menyalati jenazah di masjid menurut ulama' Syāfi'iyyah dan ulama' Ḥanābilah membolehkan selama tidak mengotori masjid. Sementara ulama' Hanafiyyah dan Mālikiyyah memakruhkannya. ${ }^{49}$ Orang yang menyalati jenazah hendaknya bertakbir minimal empat kali takbir. Boleh menambah sampai tujuh kali takbir menurut Mażhab Hanbalī. Tapi makruh makmum menunggu sampai tujuh takbir menurut Mażhab Mālikī. Harus mufāraqah (memisahkan diri) makmum terhadap imam menurut Mażhab Syāfi'ī. Sementara dalam Mażhab Hanafĩ membolehkan makmum menunggu imam dan mengucapkan salam bersama. ${ }^{50}$ Setelah takbir yang pertama,

48 Agus Riyadi, "Upaya Pemberdayaan dan Peningkatan Keterampilan Pemulasaran Jenazah," Dimas, 2, 13 (2013), h. 208.

49 'Abd al-Raḥmān al-Jazīrī, Kitāb alFiqh 'Alā al-Mażāhib al-Arba'ah, 7th ed., vol. 1 (Beirut: Dār Iḥyā’ al-Turās̀ al-’Arab̄i, 1986), h. 527.

${ }^{50}$ al-Jazīīī, 1:525. membaca surat al-Fātiḥah, setelah takbir yang kedua membaca shalawat Nabi, setelah takbir yang ketiga membaca doa untuk jenazah dan setelah takbir yang keempat mengucapkan salam. ${ }^{51}$

Penghormatan terakhir terhadap jenazah adalah menguburkannya. Tidak diperkenankan menguburkan jenazah pada waktu-waktu terbit matahari hingga naik, saat matahari istiwa' hingga condong agak ke barat, pada saat matahari mendekati terbenam dan pada kondisi dikegelapan malam. Ketentuan tersebut dapat diabaikan apabila situasi dan kondisi penguburan jenazah bersifat darurat. $^{52}$

Memasukkan mayat ke dalam kuburnya jika memungkinkan sebaiknya mendahulukan memasukkan kepala jenazah dari arah kaki kubur. Hal ini tergantung kondisi lokasi pekuburannya. Jenazah diletakkan miring melalui lambung sebelah kanan menghadap ke arah kiblat dengan menyandarkan tubuh sebelah kiri ke dinding kubur agar tidak terlentang kembali. Dianjurkan pipi sebelah kanan

51 Albani, Fiqh Lengkap Mengurus Jenazah, h. 105.

52 Albani, Fiqh Lengkap Mengurus Jenazah, h. 119. 


\section{AL-MARSHAD: JURNAL ASTRONOMI ISLAM DAN ILMU-ILMU BERKAITAN \\ ISSN 2442-5729 (print) || ISSN 2598-2559 (online) \\ http://jurnal.umsu.ac.id/index.php/almarshad \\ DOI: 10.30596/jam.v\%vi\%i.3796 || Vol. 5, No. 2 Desember 2019}

jenazah menyentuh tanah setelah kain kafannya dibuka. ${ }^{53}$

Pembuatan lubang kubur terdapat tiga metode yang biasa dilakukan oleh masyarakat. Pertama; lubang landak. Lubang ini digali didasar kubur secara menjorok disebelah barat atau sebelah kiblat. Kemudian mayat dimasukkan ke lubang tersebut. Lalu diberi dinding kayu disebelah punggungnya sebagai sekat penahan tanah. Kedua; membuat lubang di tengah-tengah dasar lubang kubur. Jenazah diletakkan di lubang tersebut yang diatasnya diberi bata atau plat semen khusus secara datar/rata untuk menahan timbunan tanah. Dan ketiga; membuat lubang kubur biasa setinggi perut orang dewasa berdiri, kira-kira 100-115 cm. Jenazah diletakkan disebelah barat/arah kiblat, kemudian diatasnya diberi papan kayu yang sudah diukur atau plata semen khusus dengan posisi agak condong untuk melindungi jenazah agar tidak langsung tertimpa tanah.

Dianjurkan pula agar tanah untuk pemakamkan jenazah ditinggikan sedikit dibandingkan dengan permukaan

\footnotetext{
53 Riyadi, "Upaya Pemberdayaan dan Peningkatan Keterampilan Pemulasaran Jenazah,” h. 213.
}

tanah lainnya, kurang lebih satu hasta, hingga membentuk seperti punuk unta. Pendapat ini disepakati oleh tiga mażhab selain Mażhab Syāfi'’̄ . Menurut Mażhab Syāfi'̄̄ bahwa meratakan tanah makam seperti permukaan tanah lainnya itu lebih afḍal daripada meninggikannya hingga membentuk seperti punuk unta. ${ }^{54}$

Hal lain yang terkait dengan kuburan adalah memberinya nisan. Selain Mażhab Syāfi'̄̄ berpendapat bahwa makruh memberi nisan dari batu, kayu atau sejenisnya kecuali dikhawatirkan tanda kuburan itu hilang karena bercampur dengan kuburan lain. Senyampang tidak untuk membanggakan diri atau agar terlihat megah. Jika untuk itu (membanggakan diri atau bermegah-megahan), maka haram hukumnya. Pendapat ini berbeda dengan pandangan Mażhab Syāfi' '̄ yang mengatakan bahwa disunnahkan memberikan nisan dari batu atau lainnya di arah kepala kuburan sebagai pembeda. ${ }^{55}$ Sementara mengecat

\footnotetext{
54 Riyadi, "Upaya Pemberdayaan dan Peningkatan Keterampilan Pemulasaran Jenazah," h. 294. Lihat juga al-Jazīrī, Kitāb alFiqh 'Alā al-Mażāhib al-Arba'ah, 1:535.$$
55 \text { al-Jazīrī, Kitāb al-Fiqh 'Alā al- }
$$
Mażāhib al-Arba'ah, 1:535.
} 


\section{AL-MARSHAD: JURNAL ASTRONOMI ISLAM DAN ILMU-ILMU BERKAITAN \\ ISSN 2442-5729 (print) || ISSN 2598-2559 (online) \\ http://jurnal.umsu.ac.id/index.php/almarshad \\ DOI: 10.30596/jam.v\%vi\%i.3796 || Vol. 5, No. 2 Desember 2019}

kuburan dengan semacam gip atau kapur, dihukumi makruh oleh semua mażhab. Apabila hanya melapisi/menimbun dengan tanah liat bukan dengan maksud memberi hiasan tidak ada masalah menurut selain Mażhab Mālikī. Namun Mażhab Mālikī melapisi kuburan itu makruh secara mutlak dengan apapun saja. ${ }^{56}$

Kebiasaan masyarakat juga adalah menulis nama si mayyit di nisan atau lainnya. Pendapat Mażhab Mālikī bahwa haram hukumnya jika yang ditulis itu berupa ayat al-Qur`ān, dan makruh jika yang ditulis adalah nama dan tanggal wafatnya. Boleh menulis kuburan jika dikhawatirkan tandatandanya hilang menurut Mażhab Hanafi. Disunnahkan menulis nama atau sejenisnya untuk kuburan orang ālim atau orang șālih untuk diketahui dan makruh selain kuburan dua orang tersebut menurut Mażhab Syāfi'ī. Dan hukumnya makruh menulis apapun di kuburan tanpa ada perkecualian orang yang dikubur menurut pendapat Mażhab Hanafí. ${ }^{57}$

Konklusinya bahwa apapun yang dilakukan orang yang masih hidup

\footnotetext{
56 al-Jazīrīi, 1:535.

${ }^{57}$ al-Jazīrīi, 1:535-36.
}

terhadap kuburan seseorang dikembalikan kepada niat dan maksudnya. Sepanjang tidak diniatkan untuk membanggakan diri, golongan, mażhab atau lainnya maka sah-sah saja memberi tanda baik dengan nisan, tulisan atau lainnya yang wajar. Karena hakikatnya makam/kuburan itu sebagai bentuk peringatan dan ibrah bagi yang masih hidup. ${ }^{58}$ Sebagaimana nabi memberikan contoh kepada segenap umatnya.

\section{H. Kiblat dalam penguburan jenazah}

Ka'bah pada awalnya sebagai kiblat (hadapan) bagi orang Islam yang melaksanakan shalat sesuai dengan ayat dan hadits yang telah penulis paparkan diatas. Seiring dengan perkembangan peribadatan bagi umat Islam, Ka'bah tidak hanya menjadi hadapan ketika shalat saja. Misalnya ketika berdo'a, berwuḍu', wirid, żikir, ażan, iqāmah, menyembelih binatang ternak, dan membaca al-Qur'ān dianjurkan (disunnahkan) menghadap kiblat (Ka'bah).

Selain yang tersebut diatas, hal lain yang juga dihadapkan ke arah kiblat adalah jenazah saat dilakukan

${ }^{58}$ al-Jazīrī, 1:536. 


\section{AL-MARSHAD: JURNAL ASTRONOMI ISLAM DAN ILMU-ILMU BERKAITAN \\ ISSN 2442-5729 (print) || ISSN 2598-2559 (online) \\ http://jurnal.umsu.ac.id/index.php/almarshad \\ DOI: 10.30596/jam.v\%vi\%i.3796 || Vol. 5, No. 2 Desember 2019}

penguburan. Hal ini berdasarkan hadis

Nabi Muhammad Saw:

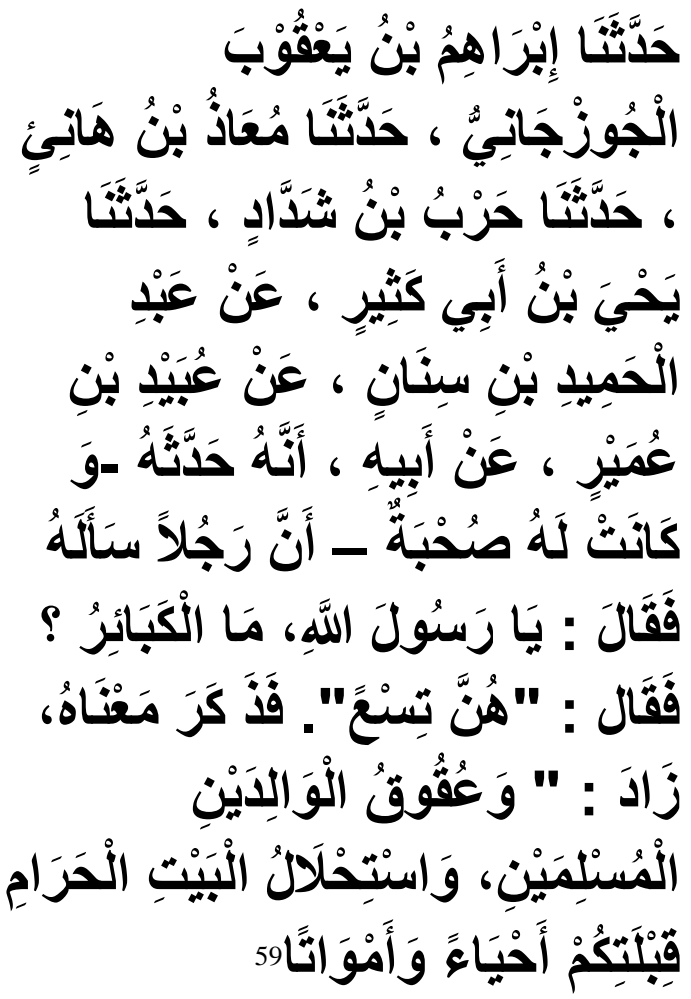

Bercerita kepada kami Ibrāhim bin Ya'qūb al-Juzjānī, bercerita kepada kami Mu'àż bin Hānik, menyampaikan cerita kepada kami Harb bin Syaddād, mengabarkan

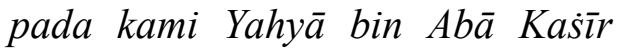
dari 'Abd al-Hamīd bin Sinān, dari 'Ubaid bin 'Umair, dari bapaknya bahwa bapaknya menceritakan kepada 'Umair (dan beliau merupakan salah satu dari sahabat nabi) bahwa seorang laki-laki bertanya kepada Nabi, lalu berkata wahai Rasūl apa itu dosa besar? Rasūl menjawab: "Dosa besar itu ada 9", lalu Nabi Muhammad menjelaskan artinya, kemudian beliau menambahkan: "Durhaka

59 Abū Dāwūd Sulaimān bin al-Asy'as al-Sijistān̄̄, Sunan Abū Dāwūd, vol. 3 (Beirut: Dār al-Fikr, 2011), h. 6. kepada kedua orang tua yang muslim, dan menghalalkan segala sesuatu yang tidak diperbolehkan di Makkah yakni Masjid al-Harām kiblatnya orang muslim baik dalam keadaan hidup maupun mati."

Menilik hadis diatas bahwa Masjid al-Ḥarām yang didalamnya terdapat Ka'bah merupakan kiblat bagi orang yang masih hidup ataupun sudah meninggal dunia. Hal ini mengindikasikan bahwa jenazah di dalam kuburnya harus dihadapkan ke arah kiblat. Berdasarkan penelusuran penulis, bahwa wajib hukumnya menghadapkan jenazah dalam kuburnya ke arah kiblat dengan posisi miring ke sebelah kanan menurut pandangan tiga mażhab; Hanafī, Syāfí'̄ dan Hanbalī. Sedangkan menurut Mażhab Mālikī bahwa mayat hanya sunnah, tidak wajib dihadapkan ke kiblat. ${ }^{60}$ Apabila orang yang meletakkan jenazah di dalam kuburnya tidak menghadap ke arah kiblat misalnya, lalu setelah itu jenazah tersebut ditutup dengan tanah, maka makam tersebut tidak perlu digali kembali untuk memperbaiki posisinya. Hukum ini disepakati oleh mażhab Ḥanafī dan Mālikī. Sedangkan menurut

60 al-Jazīīi, Kitāb al-Fiqh 'Alā alMażāhib al-Arba'ah, 1:535. 


\section{AL-MARSHAD: JURNAL ASTRONOMI ISLAM DAN ILMU-ILMU BERKAITAN \\ ISSN 2442-5729 (print) || ISSN 2598-2559 (online) \\ http://jurnal.umsu.ac.id/index.php/almarshad \\ DOI: 10.30596/jam.v\%vi\%i.3796 || Vol. 5, No. 2 Desember 2019}

mażhab Syāfi'ì dan Hambalī apabila dimakamkan tidak dengan menghadap arah kiblat maka makamnya wajib digali kembali agar posisi jenazah diperbaiki hingga menghadap ke arah kiblat. ${ }^{61}$

Dengan demikian dapat disimpulkan bahwa jenazah ketika diletakkan dalam kuburnya wajib dihadapkan ke arah kiblat berdasarkan pendapat mayoritas ulama' dari Mażhab Ḥanafì, Syāfi' '̄ dan Ḥanbalī. Sedangkan menurut pandangan ulama' Mażhab Mālikī bersifat sunnah atau tidak wajib menghadapkan mayat ke arah kiblat dalam kuburnya.

\section{Metode Penentuan Arah Kiblat Pemakaman Desa Ponteh}

Dalam menentukan arah kiblat terdapat dua macam metode yakni metode taqribī (perkiraan) dan metode taḥqīq $\bar{l} \quad$ (perhitungan). Setelah melakukan wawancara dengan beberapa informan terkait penentuan arah kiblat di tiga pemakaman di Desa Ponteh, bahwa masyarakat (khususnya penggali kubur) hanya menggunakan satu metode dalam menentukan arah kiblat. Yaitu metode taqribī (perkiraan). Itupun

${ }^{61}$ al-Jazīīi $1: 535$. tanpa menggunakan peralatan apapun seperti kompas misalnya. Metode yang digunakan hanya berdasarkan perasaan dan petunjuk arah dengan menandai peredaran matahari dan arah masjid yang ada disekitar pemakaman.

Data yang dihasilkan dalam model taqribī cukup dengan mengetahui titik mata angin utama, yaitu utara, timur, selatan dan barat. Penentuan arah kiblatnya menggunakan pengetahuan yang sudah biasa dipahami oleh mayoritas masyarakat Indonesia bahwa arah kiblat menghadap ke barat agak condong sedikit ke utara. Jadi masyarakat Desa Ponteh melakukannya dengan cara yang sama pula. Masyarakat hanya berpatokan pada teori bahwa arah kiblat adalah arah menuju ke barat dan sedikit agak miring ke utara. Maka dari itu dalam hal menentukan arah kiblat pemakaman dan membuat lubang kubur masyarakat menggunakan metode perkiraan sebagaimana yang dijelaskan diatas.

Penentuan arah kiblat menggunakan metode ini sudah biasa dilakukan oleh orang yang telah memiliki pengetahuan dasar sederhana tentang posisi Ka'bah dilihat dari lokasi setempat. Posisi arah Ka'bah apabila 


\section{AL-MARSHAD: JURNAL ASTRONOMI ISLAM DAN ILMU-ILMU BERKAITAN \\ ISSN 2442-5729 (print) || ISSN 2598-2559 (online) \\ http://jurnal.umsu.ac.id/index.php/almarshad \\ DOI: 10.30596/jam.v\%vi\%i.3796 || Vol. 5, No. 2 Desember 2019}

dilihat dari tempat pengukuran cukup dikenali apakah posisinya lurus, miring ke kanan, atau miring ke kiri sesuai arah mata angin utama tersebut sekalipun tanpa melakukan perhitungannya terlebih dahulu. Tetapi faktanya yang menentukan arah kiblat pemakaman di Desa Ponteh ini ditentukan oleh penggali kubur yang pengetahuan mengenai arah kiblat bisa dikatakan minim. Atau bahkan tidak mengetahui sama sekali. Penggali kubur melakukannya hanya dengan mengirangira dimana letak arah kiblat. Tentunya cara atau metode tersebut akurasinya sangat rendah. Di tambah lagi penggali kubur harus menyesuaikan dengan posisi makam-makam yang sudah ada di sampingnya. Dikarenakan di setiap tempat pemakaman lahannya sudah hampir penuh dengan kuburan. Sehingga barisan kuburan terlihat tidak rapi dan jarak antara satu makam dengan makam yang lainnya saling berdekatan.

Rata-rata lokasi tiga pemakaman di Desa Ponteh sudah berusia cukup tua. Seperti pemakaman Ajih yang berada di Dusun Kramat dan pemakaman Bânger yang ada di Dusun Langtolang misalnya. Kedua pemakaman ini sudah digunakan sejak zaman belanda atau sebelum Indonesia merdeka. Walaupun keduanya telah digunakan sejak zaman penjajahan Belanda, menurut penuturan informan bahwa yang lebih dulu digunakan adalah pemakaman Ajih. Sementara pemakaman Kaèl yang ada di Dusun Karangpanasan digunakan mulai tahun 1942. Lebih akhir dari dua pemakaman sebelumnya.

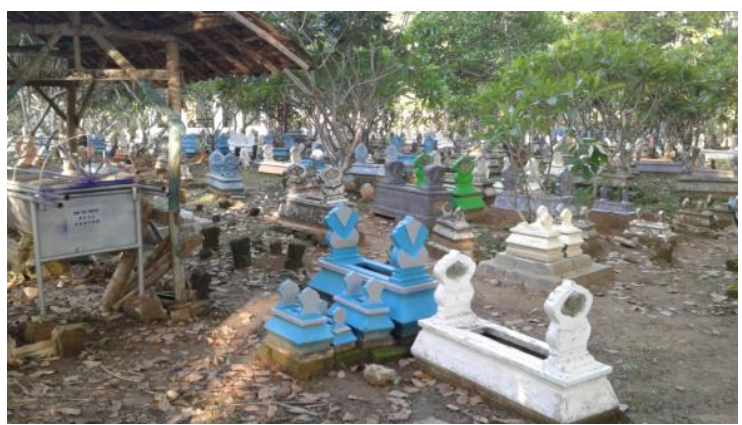

Pemakaman Ajih Dusun Kramat

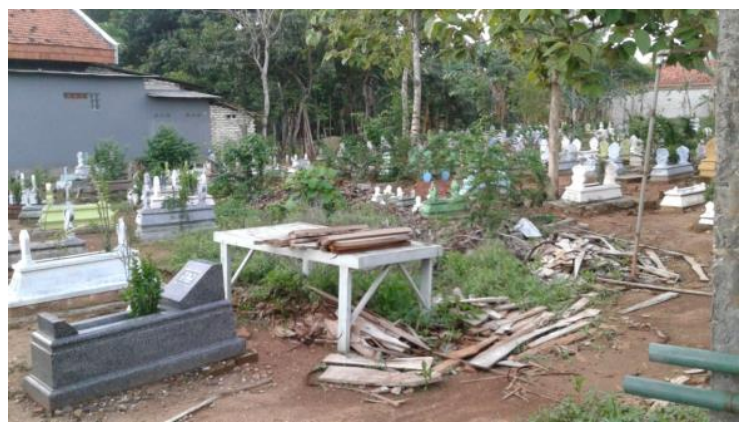

Pemakaman Bânger Dusun Langtolang

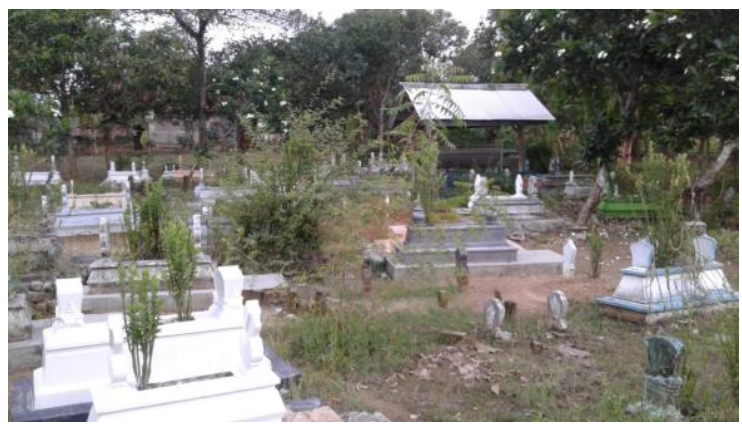


AL-MARSHAD: JURNAL ASTRONOMI ISLAM DAN ILMU-ILMU BERKAITAN

ISSN 2442-5729 (print) || ISSN 2598-2559 (online)

http://jurnal.umsu.ac.id/index.php/almarshad

DOI: 10.30596/jam.v\%vi\%i.3796 || Vol. 5, No. 2 Desember 2019

Pemakaman Kaèl Dusun

Karangpanasan

Tanah pemakaman/pekuburan yang ada di Desa Ponteh Kecamatan Galis merupakan tanah wakaf dari warga setempat pada zaman dahulu. Namun sampai sekarang tanah-tanah dimaksud belum di akta wakafkan secara resmi pada Kantor Urusan Agama setempat.

\section{J. Akurasi Arah Kiblat Pemakaman Desa Ponteh}

Metode yang digunakan dalam penelitian ini adalah metode perhitungan spherical trigonometri (segitiga bola) dengan panduan arah utara geografis sistem taḥqiqqi. Metode ini dipergunakan dengan pertimbangan, bahwa metode ini lebih memberikan ketepatan dan akurasi yang tinggi dibanding metode taqribi $\bar{\imath}$ yang hanya menggunakan perkiraan semata. Rumus spherical trigonometry yang digunakan dalam metode ini dengan sendirinya telah memperhitungkan bentuk bumi bulat laksana bola. Sehingga hasil perhitungannya presisi terhadap keadaan bumi yang sesungguhnya.

Langkah pertama yang dilakukan peneliti adalah menghitung arah kiblat masing-masing lokasi pemakaman. Data titik koordinat untuk masing-masing lokasi pemakaman diperoleh dari data GPS (Global Positioning System) pada software Google Map yang telah diinstal di handphone berbasis android (Samsung S3 mini). Data koordinat masingmasing lokasi pemakaman sebagaimana berikut:

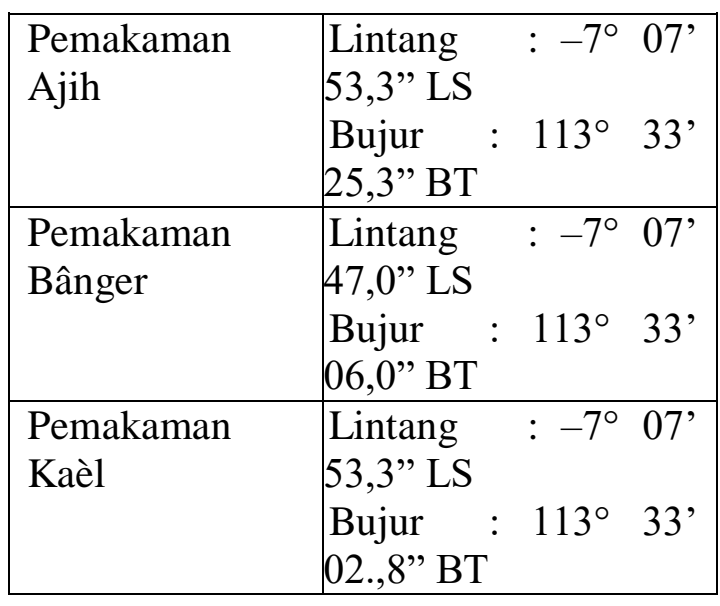

Sedangkan untuk nilai lintang dan bujur Ka'bah peneliti menggunakan hasil perhitungan yang telah digunakan sebagai panduan selama perkuliahan yaitu dengan harga lintang $21^{\circ} 25^{\prime}$ 21,04" LU dan harga bujur $39^{\circ} 49^{\prime}$ 34,33 " BT. ${ }^{62}$

62 Slamet Hambali, Ilmu Falak; Arah Kiblat Setiap Saat, ed. Ahmad Fadholi and Ismail Khudhari, I (Yogyakarta: Pustaka Ilmu, 2013), h. 14. 


\section{AL-MARSHAD: JURNAL ASTRONOMI ISLAM DAN ILMU-ILMU BERKAITAN \\ ISSN 2442-5729 (print) || ISSN 2598-2559 (online) \\ http://jurnal.umsu.ac.id/index.php/almarshad \\ DOI: 10.30596/jam.v\%vi\%i.3796 || Vol. 5, No. 2 Desember 2019}

Perhitungan arah kiblat dilakukan secara manual dengan bantuan alat hitung berupa kalkulator. Jenis kalkulator yang dipakai oleh peneliti adalah jenis kalkulator KT-350MS VC. Rumus yang digunakan adalah Cotg B $=\operatorname{cotg} \mathrm{b} \sin \mathrm{a}: \sin \mathrm{c}-\cos \mathrm{a} \operatorname{cotg} \mathrm{c}$. Dan hasil perhitungannya sebagaimana dibawah ini:

1. Pemakaman Ajih Dusun Kramat Desa Ponteh:

$\operatorname{Cotg} B=\operatorname{cotg} b \times \sin a: \sin c-$ $\cos \mathrm{a} x \operatorname{cotg} \mathrm{c}$

$\mathrm{a}=90-\left(-7^{\circ} 07^{\prime} 53,3^{\prime \prime}\right)=97^{\circ} 07^{\prime}$ 53,3 "

$\mathrm{b}=90-21^{\circ} 25^{\prime} 21,04^{\prime \prime}=68^{\circ} 34^{\prime}$ 38,96 "

$\mathrm{c}=113^{\circ} 33^{\prime} 25.3^{\prime \prime}-39^{\circ} 49^{\prime}$

$34,33^{\prime \prime}=73^{\circ} 43^{\prime} 50,97^{\prime \prime}$

Cotg $\operatorname{cotg} 68^{\circ} 34^{\prime} 38,96^{\prime \prime} \times \sin$

$\mathrm{B}=\quad 97^{\circ} 07^{\prime} 53,3^{\prime \prime}: \sin 73^{\circ} 43^{\prime}$ $50,97^{\prime \prime}-\cos 97^{\circ} 07^{\prime}$

B $53,3^{\prime \prime} \times \quad \operatorname{cotg} 73^{\circ} 43^{\prime}$

$=50,97^{\prime}$

$66^{\circ} \quad 9^{\prime} \quad 53,7^{\prime \prime}$ (dihitung dari Utara - Barat)

Harga sudut arah kiblat pemakaman Ajih adalah $66^{\circ} 9^{\prime}$ 53.7" dihitung sepanjang lingkaran horizon dari titik Utara ke Barat, atau $23^{\circ} 50^{\prime} 6.3$ " dari titik Barat ke Utara.

2. Pemakaman Bânger Dusun Langtolang Desa Ponteh:

$\operatorname{Cotg} \mathrm{B}=\operatorname{cotg} \mathrm{b} \times \sin \mathrm{a}: \sin \mathrm{c}-$ $\cos \mathrm{a} \times \operatorname{cotg} \mathrm{c}$

$\mathrm{a}=90-\left(-7^{\circ} 07^{\prime} 47,0^{\prime \prime}\right)=97^{\circ} 07^{\prime}$

47,0 "'

$\mathrm{b}=90-21^{\circ} 25^{\prime} 21,04^{\prime \prime}=68^{\circ} 34^{\prime}$

$38,96 "$ $\mathrm{c}=113^{\circ} 33^{\prime} 06,0^{\prime \prime}-39^{\circ} 49^{\prime}$

$34,33^{\prime \prime}=73^{\circ} 43$ ' $31,67^{\prime \prime}$

Cotg $\quad \operatorname{cotg} 68^{\circ} 34^{\prime} 38,96^{\prime \prime} \times$ sin

$\mathrm{B}=\quad 97^{\circ} 07^{\prime} \quad 47,0^{\prime \prime}: \sin 73^{\circ}$

43' $31,67^{\prime \prime}-\cos 97^{\circ} 07^{\prime}$ $47,0^{\prime \prime} \times \quad \operatorname{cotg} 73^{\circ} \quad 43^{\prime}$ $31,67^{\prime \prime}$

B $\quad 66^{\circ} \quad 9^{\prime} 50,87^{\prime}$ ' (dihitung $=$ dari arah Utara - Barat)

Harga sudut arah kiblat pemakaman Bânger adalah $66^{\circ}$ 9' 50,87" dihitung sepanjang lingkaran horizon dari titik Utara ke Barat, atau $23^{\circ} 50^{\prime}$ 9,13" dari titik Barat ke Utara.

3. Pemakaman Kaèl Dusun Karangpanasan Desa Ponteh:

$\operatorname{Cotg} \mathrm{B}=\operatorname{cotg} \mathrm{b} \times \sin \mathrm{a}: \sin \mathrm{c}-$ $\cos \mathrm{a} x \operatorname{cotg} \mathrm{c}$

$a=90-\left(-7^{\circ} 07^{\prime} 53,3^{\prime \prime}\right)=97^{\circ} 07^{\prime}$ 53,3 "

$\mathrm{b}=90-21^{\circ} 25^{\prime} 21,04^{\prime \prime}=68^{\circ} 34^{\prime}$ 38,96 "

$\mathrm{c}=113^{\circ} 33^{\prime} 02,8^{\prime \prime}-39^{\circ} 49^{\prime}$ $34,33^{\prime \prime}=73^{\circ} 43^{\prime} 28,47^{\prime \prime}$

Cotg $\operatorname{cotg} 68^{\circ} 34^{\prime} 38,96^{\prime \prime} \times \sin$ $\mathrm{B}=\quad 97^{\circ} 07^{\prime} \quad 53,3^{\prime \prime}: \sin 73^{\circ}$ $43^{\prime} 28,47^{\prime \prime}-\cos 97^{\circ} 07^{\prime}$ $53,3^{\prime \prime} \times \quad x \quad \operatorname{cotg} 73^{\circ} \quad 43^{\prime}$ $28,47^{\prime \prime}$

B $\quad 66^{\circ} \quad 9^{\prime} 48,93$ ' (dihitung $=\quad$ dari arah Utara - Barat)

Harga sudut arah kiblat pemakaman Kaèl adalah $66^{\circ} 9^{\prime}$ 48,93" dihitung sepanjang lingkaran horizon dari titik Utara ke Barat, atau $23^{\circ} 50^{\prime} 11,07^{\prime \prime}$ dari titik Barat ke Utara. 


\section{AL-MARSHAD: JURNAL ASTRONOMI ISLAM DAN ILMU-ILMU BERKAITAN \\ ISSN 2442-5729 (print) || ISSN 2598-2559 (online) \\ http://jurnal.umsu.ac.id/index.php/almarshad \\ DOI: 10.30596/jam.v\%vi\%i.3796 || Vol. 5, No. 2 Desember 2019}

Kedua, mempersiapkan

perlengkaan peralatan yang menjadi sarana pengukuran, seperti; kompas magnetik, penggaris busur, benang, gunting, paku dan palu. Selanjutnya langkah ketiga adalah mengukur lokasi pemakaman berdasarkan hasil perhitungan sudut arah kiblat sesuai dengan titik koordinat masing-masing. Hal-hal yang dilakukan oleh penulis dalam mengukur sudut arah kiblat di masing-masing lokasi pemakaman adalah; (1) menentuan titik utara dan selatan masing-masing lokasi dengan kompas yang sudah diinstall ke dalam handphone (Islamic Compass Qibla Direction). Dalam hal ini penulis tidak mengoreksi arah utara kompas dengan nilai deklinasi/inklinasi medan magnet bumi. Kemudian dari petunjuk arah utara dan selatan ditandai dengan benang yang dikaitkan pada paku yang sudah ditancapkan, (2) menentukan arah timur dan barat dengan mengukurnya melalui penggaris busur. Berikutnya menandai arah tersebut dengan benang yang dikaitan pada paku, (3) menandai arah kiblat sesuai hasil perhitungan dengan benang berpedoman pada angka yang terdapat pada penggaris busur, dan (4) menandai arah kiblat kuburan dengan benang yang dikaitkan pada paku.

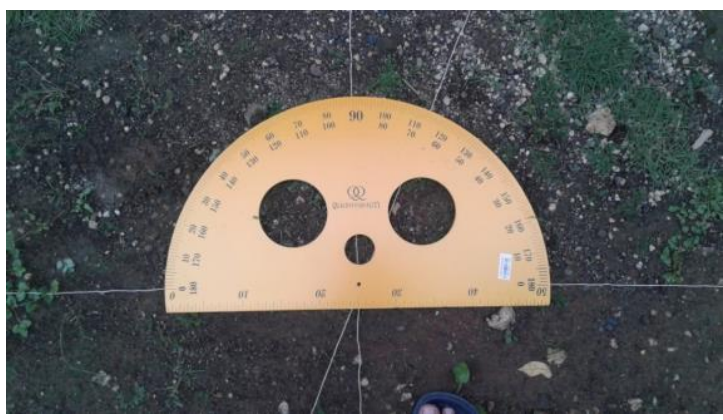

Pengukuran di pemakaman Ajih

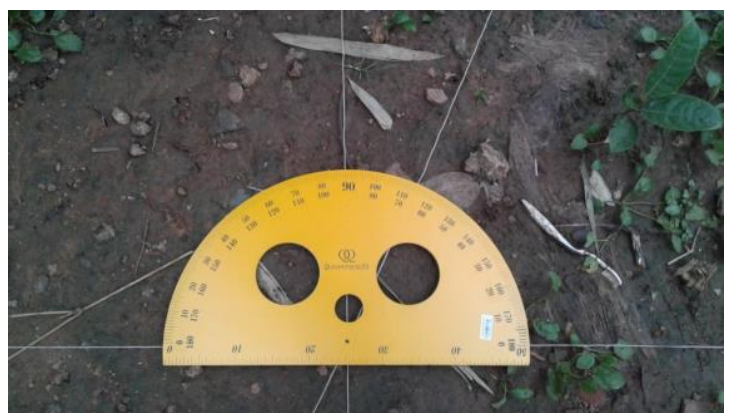

Pengukuran di pemakaman Bânger

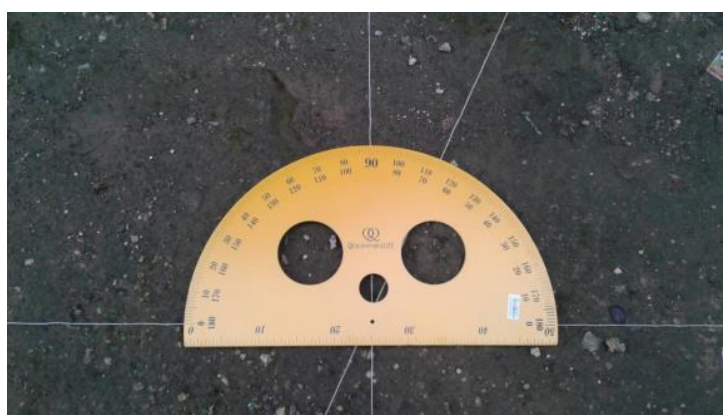

Pengurkuan di pemakaman Kaèl

Keempat; menganalisis akurasi arah kiblat pemakaman dengan menghitung selisih antara garis arah kiblat sesuai perhitungan dengan garis arah kiblat kuburan. Dalam analisis ini penulis menggunakan sampel untuk masing-masing pemakaman sebanyak 


\section{AL-MARSHAD: JURNAL ASTRONOMI ISLAM DAN ILMU-ILMU BERKAITAN \\ ISSN 2442-5729 (print) || ISSN 2598-2559 (online) \\ http://jurnal.umsu.ac.id/index.php/almarshad \\ DOI: 10.30596/jam.v\%vi\%i.3796 || Vol. 5, No. 2 Desember 2019}

50 kuburan yang saling

berkelompok/berdekatan posisinya.

Analisis akurasi yang dilakukan oleh penulis dibagi menjadi beberapa kategori, yaitu; sesuai dengan arah kiblat hitungan ilmu falak, deviasi $1^{\circ}-$ $5^{\circ}$ kurang ke utara/selatan, penyimpangan $6^{\circ}-10^{\circ}$ kurang ke utara/selatan, melenceng $10^{\circ}$ keatas baik kurang ke utara/selatan.

Hasil akurasi arah kiblat untuk masing-masing lokasi pemakaman menunjukkan bahwa makam/kuburan yang arah kiblatnya sesuai dengan hasil perhitungan ilmu falak, untuk di pemakaman Ajih 3 kuburan (6\%), pemakaman Bânger 6 kuburan (12\%) dan pemakaman Kaèl nihil (0\%). Makam yang arah kiblatnya $1^{\circ}-5^{\circ}$ kurang ke utara, pemakaman Ajih 14 makam (28\%), pemakaman Bânger 26 makam (52\%) dan pemakaman Kaèl 11 makam (22\%). Makam yang arah kiblatnya $1^{\circ}-5^{\circ}$ kurang ke selatan, pemakaman Ajih 2 makam (4\%), pemakaman Bânger 3 makam (6\%) dan pemakaman Kaèl nihil (0\%).

Sementara kuburan yang arah kiblanya mengalami deviasi $6^{\circ}-10^{\circ}$ kurang ke utara, untuk pemakaman Ajih 30 kuburan (60\%), pemakaman Bânger
11 kuburan (22\%) dan pemakaman Kaèl 14 kuburan (28\%). Makam yang deviasinya $6^{\circ}-10^{\circ}$ kurang ke selatan, pemakaman Ajih nihil (0\%), pemakaman Bânger 3 kuburan (6\%) dan pemakaman Kaèl nihil (0\%). Sedangkan yang melenceng lebih dari $10^{\circ}$ kurang ke utara, pemakaman Ajih dan pemakaman Bânger masing-masing 1 kuburan (2\%), dan pemakaman Kaèl 25 kuburan (50\%). Untuk kategori terakhir, yaitu makam yang mengalami penyimpangan arah kiblat $10^{\circ}$ keatas kurang ke selatan ternyata tidak terdapat di semua pamekaman.

Berdasarkan hasil analisis sebagaimana tersebut diatas, bahwa disetiap pemakaman dari sampel yang digunakan, kuburan yang arah kiblatnya sesuai dengan perhitungan trigonometri ilmu falak dibawah 15\%. Bahkan di pemakaman Kaèl tidak ada sama sekali alias nihil. Hal ini disebabkan karena pertama, masyarakat tidak pernah melakukan perhitungan dan pengukuran di masing-masinig pemakaman tersebut sejak awal digunakan hingga saat ini. Dalam menentukan arah kiblat penguburan jenazah didasarkan pada perkiraan dan keyakinan perasaan semata. Kedua, masyarakat membuat 


\section{AL-MARSHAD: JURNAL ASTRONOMI ISLAM DAN ILMU-ILMU BERKAITAN \\ ISSN 2442-5729 (print) || ISSN 2598-2559 (online) \\ http://jurnal.umsu.ac.id/index.php/almarshad \\ DOI: 10.30596/jam.v\%vi\%i.3796 || Vol. 5, No. 2 Desember 2019}

lubang kubur dengan hanya mengikuti arah dari tanah pemakaman saja. Disisi lain mengikuti posisi kuburan yang sudah ada sebelumnya ditempat para penggali kubur membuat lubang lahat baru. Dan ketiga, tidak akuratnya arah kiblat pemakaman juga disebabkan tempat pemakaman sudah hampir penuh dan barisan shaf dari masing-masing makam sudah tidak rapi dan terkesan berantakan.

\section{K. Kesimpulan}

Berdasarkan hasil wawancara, observasi, dokumentasi, paparan data dan temuan penelitian, diperoleh kesimpulan, pertama; metode yang dipakai oleh masyarakat (khususnya penggali kubur) dalam menentukan arah kiblat makam di Desa Ponteh menggunakan metode taqribi (perkiraan) tanpa sarana pengukur seperti kompas misalnya. Metode ini didasarkan pada perkiraan dan modal keyakinan semata sesuai perasaan dengan memperkirakan arah kiblat menghadap ke barat agak condong sedikit ke utara. Terkadang penggali kubur ketika membuat liang lahat mengikuti baris kuburan yang ada disebelahnya. Atau mengikuti arah posisi tanah pemakaman. Karena para penggali kubur dan juga masyarakat dan tokoh agama setempat tidak mengetahui cara menentukan arah kiblat dengan benar sesuai ilmu falak. Kedua; akurasi arah kiblat pemakaman di Desa Ponteh Kecamatan Galis Kabupaten Pamekasan menurut hasil perhitungan diperoleh hasil arah kiblat untuk pemakaman Ajih $66^{\circ}$ 9' 53.7” (U-B), pemakaman Bânger $66^{\circ}$ ' 9' 50,87’ (U-B), dan pemakaman Kaèl 66 9' 48,93” (U-B). Dari sampel sebanyak 50 makam berdasarkan pengelompokan dimasingmasing pemakaman, diperoleh data makam yang sesuai arah kiblatnya hanya $6 \%$ di pemakaman Ajih, $12 \%$ di pemakaman Bânger dan di pemakaman Kaèl tidak ada kuburan yang akurat arah kiblatnya sama sekali. Kuburan yang deviasi arah kiblatnya $1^{\circ}-5^{\circ}$ ke utara, pemakaman Ajih 2 makam (4\%), pemakaman Bânger 3 makam (6\%) dan pemakaman Kaèl nihil (0\%). Yang $1^{\circ}$ $5^{\circ}$ ke selatan, di pemakaman Ajih 14 makam (28\%), pemakaman Bânger 26 makam (52\%) dan pemakaman Kaèl 11 makam (22\%). Melenceng $6^{\circ}-10^{\circ} \mathrm{ke}$ utara, pemakaman Ajih nihil (0\%), pemakaman Bânger 3 kuburan (6\%) dan pemakaman Kaèl nihil (0\%). 


\section{AL-MARSHAD: JURNAL ASTRONOMI ISLAM DAN ILMU-ILMU BERKAITAN \\ ISSN 2442-5729 (print) || ISSN 2598-2559 (online) \\ http://jurnal.umsu.ac.id/index.php/almarshad \\ DOI: 10.30596/jam.v\%vi\%i.3796 || Vol. 5, No. 2 Desember 2019}

Melenceng $6^{\circ}-10^{\circ}$ ke selatan, untuk pemakaman Ajih 30 kuburan (60\%), pemakaman Bânger 11 kuburan (22\%) dan pemakaman Kaèl 14 kuburan (28\%). Terakhir, kuburan yang melenceng dari arah kiblat lebih dari $10^{\circ}$ ke utara tidak ditemukan di masingmasing pemakaman, tetapi yang melencengnya lebih dari $10^{\circ}$ ke selatan ditemukan pemakaman Ajih dan pemakaman Bânger masing-masing 1 kuburan (2\%), dan pemakaman Kaèl 25 kuburan (50\%).[]

\section{Daftar Pustaka}

Afifuddin, Moch. "Uji Akurasi Arah Kiblat Pemakaman Berdasarkan Metode Sinus Cosinus." Skripsi, UIN Maliki, 2012.

Albani, M. Nashiruddin. Fiqh Lengkap Mengurus Jenazah. Translated by A.M. Basalamah. Jakarta: Gema Insani Press, 2014.

Amin, KH. Ma'ruf, H. M. Ichwan Sam, Hasanuddin AF, H. Hasanuddin, and H. M. Asrorun Ni'am Sholeh. Himpunan Fatwa Majelis Ulama Indonesia Sejak 1975. Edited by Hijrah Saputra, Andriyansyah, and Adhika Prasetya K. 14th ed. Jakarta: Erlangga, 2011.
Azhari, H. Susiknan. Ensiklopedi Hisab Rukyat. 3rd ed. Yogyakarta: Pustaka Pelajar, 2012.

—. Ilmu Falak; Perjumpaan Khazanah Islam dan Sains Modern. Yogyakarta: Suara Muhammadiyah, 2007.

Badan Hisab \& Rukyat Departemen Agama. Almanak Hisab Rukyat. Jakarta: Proyek Pembinaan Badan Peradilan Agama Islam, 1981.

Bagawī, Abī Muḥammad al-Ḥusain bin Mas'ūd al-. Tasīr al-Bagawī Ma'îlim al-Tanzīl. Vol. 2. 8 vols. Riyāḍ: Dār al-Ṭayyibah, 1409.

Bashori, Muhammad Hadi. Pengantar Ilmu Falak: Pedoman Lengkap Tentang Teori dan Praktik Hisab, Arah Kiblat, Waktu Salat, Awal Bulan Qamariah \& Gerhana. Pustaka Al Kautsar, 2015.

Bukhārī, Abū 'Abdullāh Muḥammad bin Ismā'îl al-. al-Jāmi' al-Ṣaḥ̂hh. I. Vol. 1. 4 vols. Kairo: alSalafiyyah, 1400.

Butar-Butar, Arwin Juli Rakhmadi. Kakbah dan Problematika Arah Kiblat. Yogyakarta: Museum Astronomi Islam, cet. I, 2013. 


\section{AL-MARSHAD: JURNAL ASTRONOMI ISLAM DAN ILMU-ILMU BERKAITAN \\ ISSN 2442-5729 (print) || ISSN 2598-2559 (online) \\ http://jurnal.umsu.ac.id/index.php/almarshad \\ DOI: 10.30596/jam.v\%vi\%i.3796 || Vol. 5, No. 2 Desember 2019}

Damisyq̄ī, 'Imād al-Dīn Abī al-Fidā' Ismā'îl bin Kas̄īr al-. Tafsīr alQur'ān al-'Azìm. Edited by Mușțafā al-Sayyid Muhammad, Muhammad Fadhl al-'Ajmāwī, Muhammad al-Sayyid Rasyād, 'Al̄̄ Ahmad 'Abd al-Bāqī, and Hasan ’Abbās Quṭb. I. Vol. 2. 15 vols. Kairo: Aulād al-Syaikh li alTurās, 2000.

Daud, Mohd. Kalam, and Muhammad Kamalussafir. "Akurasi Arah Kiblat Komplek Pemakaman Ditinjau Menurut Kaidah Trigonometri (Studi Kasus di Kecamatan Syiah Kuala Kota Banda Aceh).” Samarah, 2, 2 (July 2018): 502-29.

Departemen Agama RI. Syaamil alQur'an The Miracle 15 in 1. Bandung: PT. Sygma Examedia Arkanleema, 2009.

Fatḥullāh, Aḥmad Gazālī Muḥammad. Anfa' al-Wasīlah ilā Ma'rifah alAuqāt al-Syar'iyyah wa Simt alQiblah. Sampang: Ponpes alMubarak Lanbulan, n.d.

Hafidz, Ahsin W. Kamus Ilmu alQur`an. Jakarta: Amzah, 2012.

Hambali, Slamet. Ilmu Falak; Arah Kiblat Setiap Saat. Edited by
Ahmad Fadholi and Ismail Khudhari. I. Yogyakarta: Pustaka Ilmu, 2013.

Haroen, H. Nasrun. Ensiklopedi Hukum Islam. Edited by H. Abdul Aziz Dahlan, Satria Effendi M. Zein, Jimli Asshiddiqie, H. Said Aqil Husin al-Munawar, $\mathrm{H}$. Muhammad Amin Suma, H. M. Yunan Yusuf, H. Fathurrahman Djamil, and H. Badri Yatim Yatim. 1st ed. Vol. 3. 4 vols. Jakarta: Ichtiar Baru van Hoeve, 1996.

Ikk, Khālid 'Abd al-Raḥmān al-'. Tashīl Al-Wușūl Ilā Ma'rifah Asbāb alNuzūl. I. Beirut: Dār al-Ma'rifah, 1998.

Izzan, Ahmad, and Iman Saifullah. Studi Ilmu Falak: Cara Mudah Belajar Ilmu Falak. Banten: Pustaka Aufa Media Press, 2013. Jazīrī, 'Abd al-Raḥmān al-. Kitāa alFiqh 'Alā al-Mażāhib al-Arba'ah. 7th ed. Vol. 1. 4 vols. Beirut: Dār Iḥyā’ al-Turāì al-’Arabī, 1986.

Khazin, Muhyiddin. Kamus Ilmu Falak. Yogyakarta: Buana Pustaka, 2005.

Khoironi, Misbahul. "Penentuan Arah Qiblah Pemakaman (Persepsi 


\section{AL-MARSHAD: JURNAL ASTRONOMI ISLAM DAN ILMU-ILMU BERKAITAN \\ ISSN 2442-5729 (print) || ISSN 2598-2559 (online) \\ http://jurnal.umsu.ac.id/index.php/almarshad \\ DOI: 10.30596/jam.v\%vi\%i.3796 || Vol. 5, No. 2 Desember 2019}

Masyarakat dalam Penentuan

Arah Qiblah Pemakaman di

Kecamatan Ngunut Kabupaten

Tulungagung)." Skripsi, IAIN

Tulungagung, 2018.

Kuncoro, Kathon Bagus. "Arah Kiblat

Komplek Pemakaman Sewulan

Kabupaten Madiun Berdasarkan

Metode Imam Nawawi al-

Bantani." Skripsi, UIN Maliki, 2016.

Ma'nawi, Muhammad Mannan. "Studi

Analisis Metode Penentuan Arah

Kiblat Maqbarah BHRD

Kabupaten Rembang." Skripsi,

IAIN Walisongo, 2011.

Manẓūr, Ibn. Lisān al-'Arab. Vol. 5. 6 vols. Kairo: Dār al-Ma’ārif, n.d.

Lisān al-'Arab. Vol. 4. 6 vols.

Kairo: Dār al-Ma'ārif, n.d.

. Lisān al-'Arab. Vol. 1. 6 vols.

Kairo: Dār al-Ma’ārif, n.d.

Mulyadi, Achmad. "Akurasi Arah

Kiblat Masjid-Masjid di

Kabupaten Pamekasan." Nuansa,

1, 10 (June 2013): 72-100.

- Ilmu Hisab Rukyat. Surabaya:

Pena Salsabila, 2013.
Munawwir, Ahmad Warson. Kamus AlMunawwir; Arab-Indonesia. 1st ed. Yogyakarta: Pustaka Progresif, 1984.

Murtadho, Moh. Ilmu Falak Praktis. Malang: UIN Malang Press, 2008.

Nasution, H. Harun, Satria Effendi Zein, Iik Arifin M. Nur, Muhammad Amin, and Yunan Yusuf. Ensiklopedi Islam Indonesia. Vol. 2. 3 vols. Jakarta: Djambatan, 1992.

Riyadi, Agus. "Upaya Pemberdayaan dan Peningkatan Keterampilan Pemulasaran Jenazah.” Dimas, 2, 13 (2013): 201-20.

Sijistān̄̄, Abū Dāwūd Sulaimān bin alAsy'aṡ al-. Sunan Abū Dāwūd. Vol. 3. Beirut: Dār al-Fikr, 2011.

Syairāzī, Majd al-Dīn Muhammad bin Ya'qūb al-Fairuz Abādī al-. alQāmūs al-Muḥ̂ț. Vol. 2. 4 vols. Kairo: al-Ḥayah al-Mișriyyah, n.d.

Zabīdī, Muḥammad Murtaḍā al-Ḥusain̄̄ al-. Tāj al-'Arūs min Jawāhir alQāmūs. Vol. 15. 20 vols. Kuwait: al-Turās̀ al-'Arabī, 1960. 